\title{
32. GEOLOGIC HISTORY OF THE SOUTHEASTERN GULF OF MEXICO ${ }^{1}$
}

\author{
Wolfgang Schlager, School of Marine and Atmospheric Science, University of Miami, Miami, Florida \\ Richard T. Buffler, David Angstadt, ${ }^{2}$ and Ronald Phair, ${ }^{3}$ Institute for Geophysics, \\ University of Texas at Austin, Austin, Texas
}

\begin{abstract}
We have combined a seismic stratigraphic analysis of the southeastern Gulf of Mexico with DSDP drilling data to obtain a view of the geologic history of the area. Basement is attenuated lower Paleozoic continental crust with Lower Jurassic diabase dikes. Post-Paleozoic sedimentation began in Triassic(?)-Jurassic(?) rift grabens, probably followed by Early to Middle Jurassic terrestrial to shallow-marine clastics and Late Jurassic shallow and deep-water carbonates. By earliest Cretaceous time, much of the southeastern Gulf was a deep seaway between the carbonate platforms of Florida and Yucatan. There was a steady background of pelagic carbonate sedimentation. In addition, sedimentation was influenced by input from the adjacent platforms until middle Cretaceous, by input from the approaching Cuban island arc in Late Cretaceous-Eocene, and by steadily increasing submarine erosion from late Eocene on.

According to sediment facies and position relative to the Florida-Bahama platform, the deep southeastern Gulf, where basin Sites 535 and 540 are situated, is an extension of the Camajuani Zone in northern Cuba. The basement Sites 537 and 538 are an extension of the lower Paleozoic (Pan-African) metamorphic terrane in northern Florida. All three basement sites $(536,537$, and 538) were probably attached to Yucatan since the Early Cretaceous, as indicated by sediment facies and seismic stratigraphy.

Tectonic movements included (Triassic-Jurassic?) faulting during the rift stage, Late Jurassic-Cretaceous block faulting probably related to transcurrent movements between the Gulf and the Atlantic, and finally, faulting along the north slope of Cuba during the Late Cretaceous through Eocene interval.
\end{abstract}

\section{INTRODUCTION}

The purpose of this chapter is to summarize the regional geologic history of the southeastern Gulf of Mexico on the basis of the interpretation of multifold seismic data, collected by the University of Texas Institute for Geophysics, and the results of DSDP Leg 77. First, we discuss the seismic stratigraphy of the area and how it ties in with the drilling results. The resulting framework is used to develop a model for the geologic history of the southeastern Gulf, which is then compared with the known geologic history of surrounding provinces: Florida, Bahamas, Cuba, Yucatan, and the North Atlantic. Finally, we discuss the implication of seismic surveys and drilling for tectonic models of the early opening of the Gulf of Mexico and the collision of the $\mathrm{Cu}$ ban arc with the North American Plate.

\section{SEISMIC STRATIGRAPHIC FRAMEWORK}

The University of Texas Institute for Geophysics (UTIG) has collected an extensive grid of multifold seismic data in the southeastern Gulf of Mexico during the past few years. The study area lies north of Cuba between the Campeche and Florida escarpments (Fig. 1). Here the seafloor is shallower than the deep Gulf to the north, and is characterized by erosional channels and large knolls.

\footnotetext{
${ }^{1}$ Buffler, R. T., Schlager, W., et al., Init. Repts. DSDP, 77: Washington (U.S. Govt. Printing Office).

2 Present address: Texaco, USA, 3350 Wilshire Blvd., Los Angeles, California 90010.

3 Present address: Texaco, Inc., Box 60252, New Orleans, Louisiana 70160.
}

The seismic data were used to develop a preliminary seismic stratigraphic framework and to choose the drilling sites for Leg 77 (Fig. 2). Data for the lines designated GT-2 and GT-3 were collected in 1977 and 1978 as part of a regional study sponsored by industry. Data for the lines designated SF were collected late in 1980 as part of an IPOD site survey for Leg 77. Drilling has added ground data in several strategic locations. Shallow basement was the objective of drilling at the three western holes $(536,537$, and 538A), and penetration of a thick Mesozoic basin fill was the objective at the eastern holes (535 and 540) (Fig. 2). All these holes are projected into schematic cross-sections in Figure 3. Details of the drilling results are presented in the site chapters and specialty chapters of this volume.

The seismic data and drilling results allow, for the first time, a preliminary interpretation of the seismic stratigraphy, structural setting, and geologic history of the southeastern Gulf. This area presents the best opportunity to study the Mesozoic history because a thick section of older rocks lies at shallow depth or is exposed by erosion at the seafloor. The lack of overburden improves seismic resolution in the older sedimentary sequences and puts them within reach of the Glomar Challenger.

The deep southeastern Gulf is underlain by rifted and attenuated "transitional" crust covered by a thick sedimentary section of pre-middle Cretaceous rocks (Fig. 3). The Late Cretaceous-Cenozoic cover is relatively thin over most of the area, although it thickens considerably to the south, toward Cuba. The pre-middle Cretaceous section probably reflects an overall transition upward 


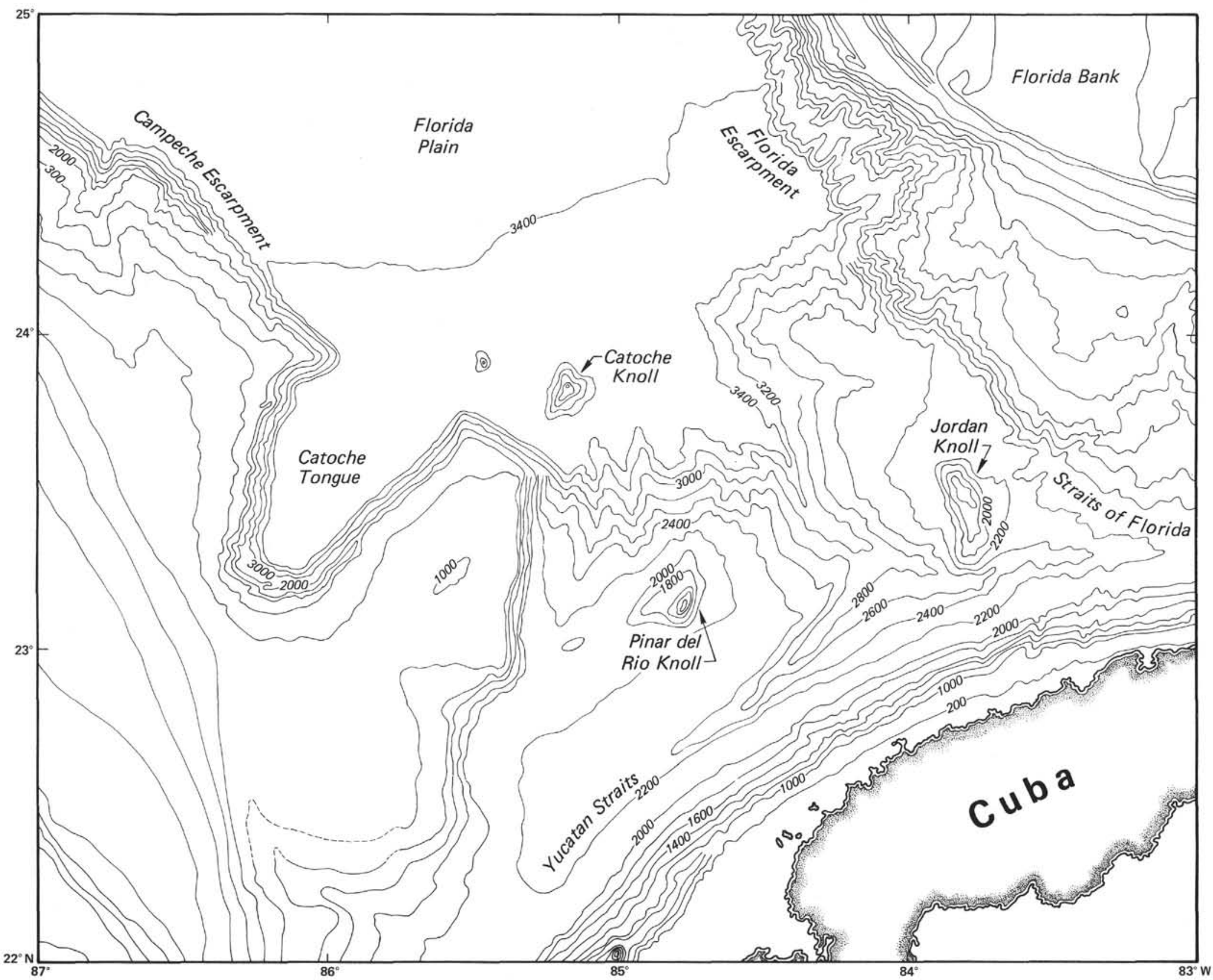




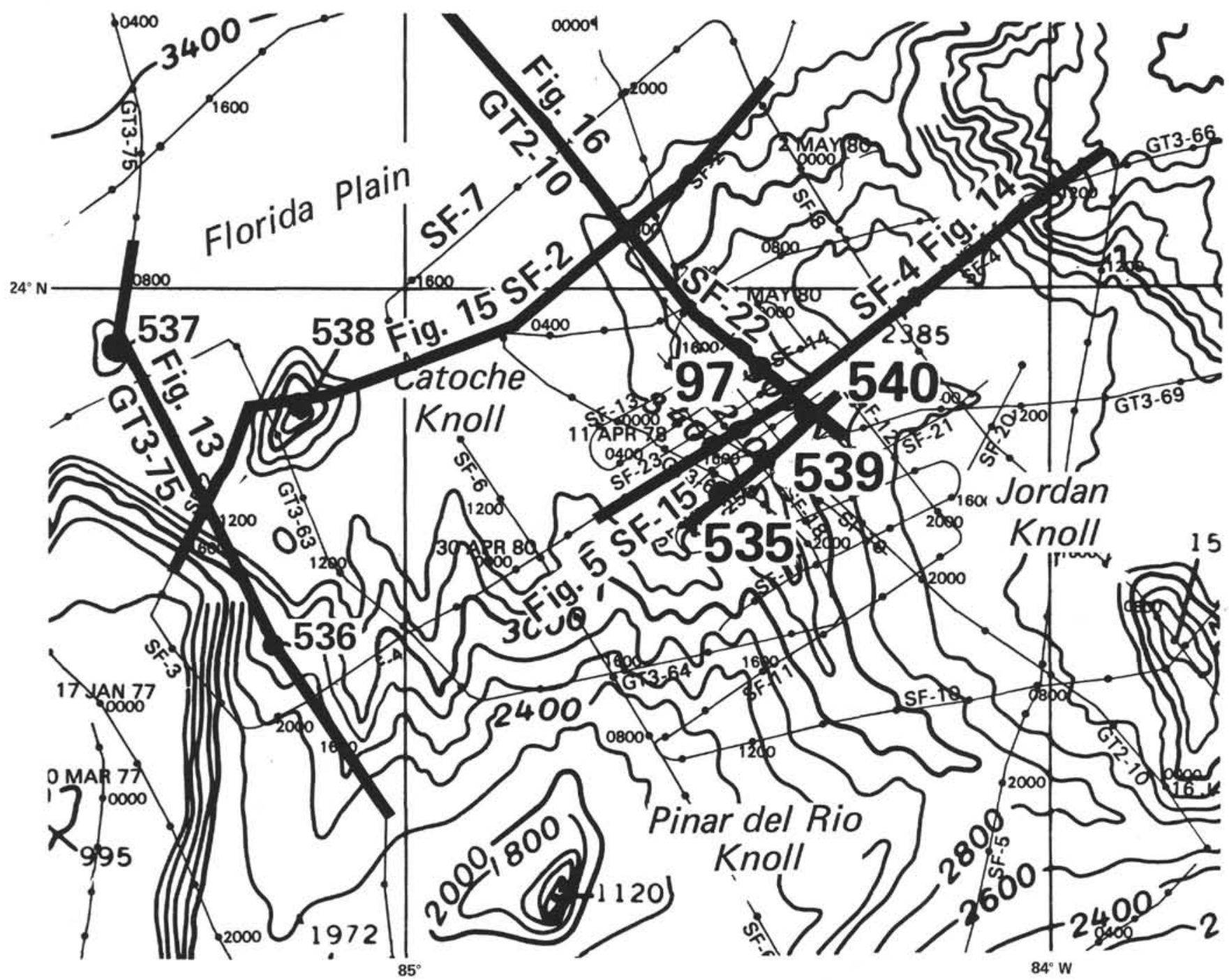

Figure 2. Map of study area, southeastern Gulf of Mexico, showing DSDP sites and locations of UTIG multifold seismic lines; heaviest lines indicate portions of seismic lines illustrated in this chapter. Water depths in meters.

from nonmarine to shallow marine and then deep marine deposits as the basin subsided.

A generalized tectonic setting for the pre-middle Cretaceous rocks is illustrated in Figure 4. The area to the north is characterized by a relatively thick section filling a subdued basement topography. Just to the south is a large area characterized by tilted fault blocks with adjacent basins filled in with syn-rift sequences. The southeastern part of the area in the vicinity of Jordan Knoll is characterized again by subdued basement relief and a thick Mesozoic section. It is flanked on the west by a large half-graben or graben trending northwest-southeast. West of the graben is a large stable block with a thick older Mesozoic(?) section that is undeformed. Cutting across the northern part of this area is an older buried graben system trending northeast-southwest. The northern margin of this stable block is faulted in such a way as to influence the topography of the seafloor. The entire area in front of Cuba has been depressed considerably to form a foredeep with over $4000 \mathrm{~m}$ of lower Ter- tiary sediments. On the west and east are the Campeche and Florida escarpments, respectively, which represent the somewhat eroded flanks of the Cretaceous carbonate platforms that rim the deep Gulf. The seismic data establish regional orthogonal fault trends in NW-SE and NE-SW directions.

The sedimentary sequences overlying basement are grouped into five main subdivisions: (1) a Late TriassicEarly Jurassic(?) rift basin (TJ); (2) a widespread Jurassic(?) nonmarine to shallow marine unit (J1); (3) a more restricted Late Jurassic(?) shallow to deep marine unit (J2); (4) a widespread Early Cretaceous unit drilled on Leg 77 (EK); and (5) a Late Cretaceous-Cenozoic unit (KC). Table 1 describes each of these major subdivisions. The Early Cretaceous and the Late CretaceousCenozoic subdivisions have been the subjects of more detailed studies (Phair, in press; Angstadt, 1983).

The Early Cretaceous (EK) rocks are divided into four main mapping units, as defined in the vicinity of Sites 535 and 540 along line SF-15 (Fig. 5). The mapping 

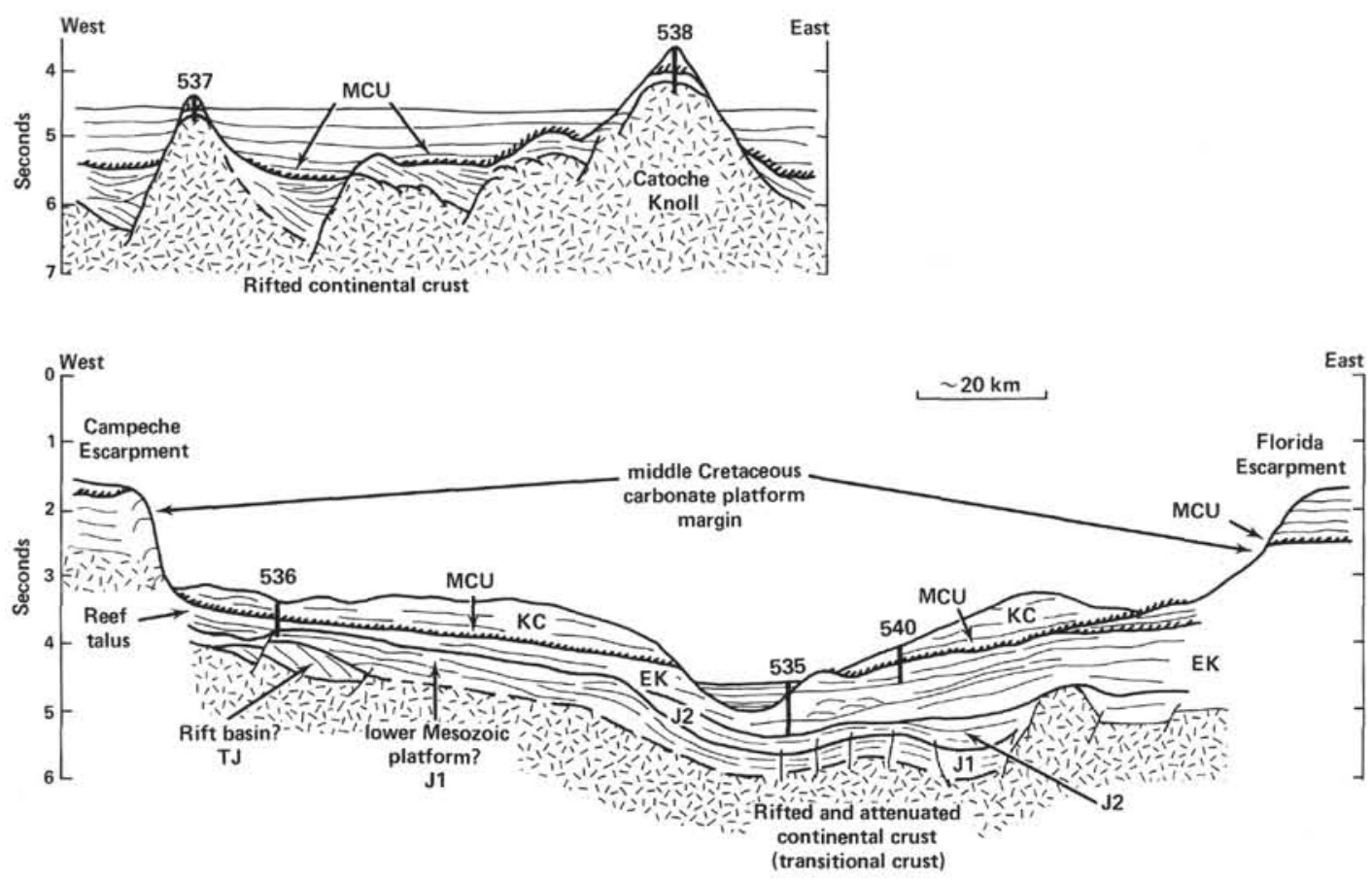

Figure 3. Schematic sections across study area, showing location of DSDP Leg 77 sites. MCU = mid-Cretaceous unconformity; TJ, J1, J2, EK, and KC are seismic units described in Table 1.

units are composed of one or more seismic sequences in the sense of Vail and others (1977). Each of the four units has been mapped, and isochron maps have been constructed to show regional thickness trends. (Isochron maps show differences in two-way traveltime and approximate isopach maps if velocity is relatively constant for the entire unit [Figs. 6-8].) The units have been tied to the DSDP Leg 77 sites (Table 2). More details of these units and the Early Cretaceous history are presented by Phair (in press).

The Early Cretaceous sequence is truncated by a prominent and important regional unconformity that is traceable throughout the Gulf of Mexico. It has been commonly referred to as the "middle Cretaceous unconformity" (MCU). In the deep southeastern Gulf, this seismic unconformity represents a large hiatus of variable duration. At Site 540, this hiatus spans almost the entire Late Cretaceous. The MCU represents a major turning point in sedimentation throughout the Gulf. It is discussed in more detail later in this chapter.

The Cretaceous-Cenozoic subdivision (KC) above the MCU is also divided into four mapping units that have been tied to the DSDP holes. Isochron maps for three of the units and a north-south cross-section (Figs. 9-12) show the thickness trends and the regional relationships. Descriptions of these units appear in Table 3. Further details of the Late Cretaceous-Cenozoic geologic history of the area are found in Angstadt, 1983.

Regional seismic lines across the area illustrate geologic features and the major subdivisions discussed in the foregoing. Specific features shown on each line are elaborated in Figures 13-16.

\section{GEOLOGIC HISTORY OF THE SOUTHEASTERN GULF OF MEXICO}

\section{Pre-Cretaceous (Basement, TR, J1, and J2 Sequences)}

The pre-Cretaceous history of the study area is very complex, as indicated by the seismic data. Except for the basement Holes 537 and 538A, there are no ground data for this chapter in the history of the southeastern Gulf. However, a scenario for the pre-Cretaceous history can be discussed on the basis of interpretation of seismic data and regional comparisons.

The southeastern Gulf is underlain by a rifted and attenuated continental crust (or "transitional crust"), as suggested first by reflection and refraction data (Buffler et al., 1981; Ibrahim et al., 1981) and later confirmed by the drilling. This area probably followed an early history similar to that of the North Atlantic-that is, a period of alteration of the crust by thermal processes in the mantle during the Late Triassic-Early Jurassic. The TJ graben system (number 6 in Fig. 4; also Fig. 13) may have formed during this period, as it has characteristics similar to Late Triassic-Early Jurassic grabens along the margins of the North Atlantic. This early rift stage was accompanied by basaltic volcanism and injection of dikes, as indicated by the 190- to 160-Ma-old dikes in Hole 538A. The rocks filling the northeast-striking graben system most likely consist of nonmarine sediments and volcanics similar to those on the margins of the North Atlantic. Alternatively, this graben system could represent unmetamorphosed Paleozoic sedimentary rocks in down-dropped fault blocks such as those in the subsurface of northern Florida. 


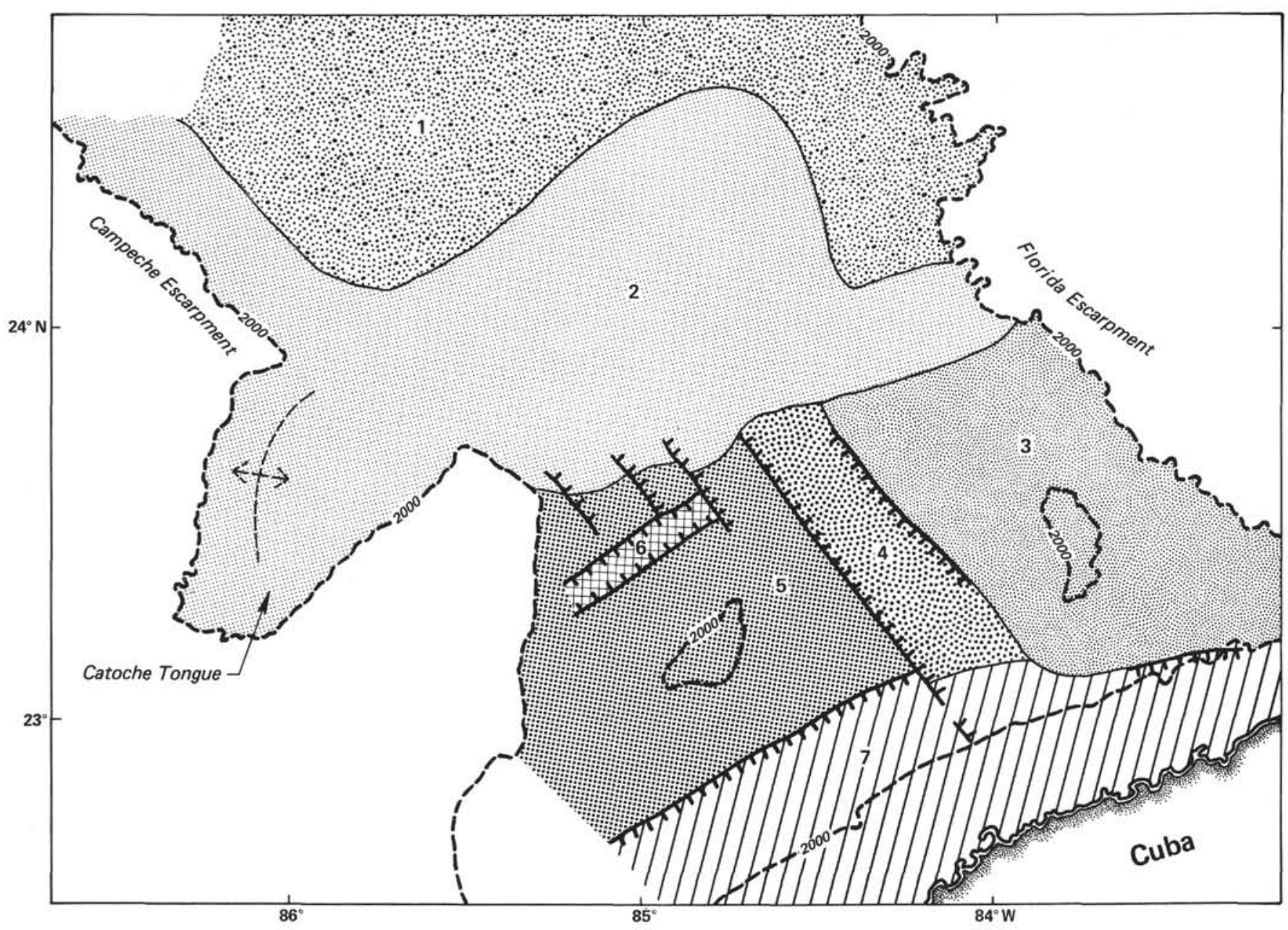

Figure 4. Sketch map showing generalized tectonic setting of study area (water depths in meters). Bold numbers designate the following tectonic provinces: (1) thick sediment section filling subdued basement topography; (2) tilted fault blocks, tectonic depressions filled with synrift sediments; (3) thick Mesozoic sediments overlying basement with subdued relief; (4) half-graben or graben; (5) untilted block with undeformed preCretaceous sediments; (6) northeast-southwest graben; (7) foredeep of Cuban fold belt.

In the Middle Jurassic, the area apparently was a broad depression characterized by large basement uplifts and basins. A widespread sedimentary unit, J1, is filling this depression. It probably consists of alluvial fans, lacustrine deposits, and volcanics. During the later part of this period, the central position of the southeastern Gulf was subjected to extensive block faulting (number 2 in Fig. 4). Older sequences were rotated to form half-grabens, and (nonmarine?) rift sediments filled the intervening basins (Fig. 15).

Intensive block faulting has been restricted to the central part of the southeastern Gulf. Farther north, the J1 unit onlaps basement and appears to pinch out toward the outer high at the inferred ocean crust-transitional crust boundary (Fig. 16). This suggests that it is older than the formation of the ocean crust.

An early transgression may have reached the area from the south late in J1 time. This conclusion is based on the shallow-marine dolomite drilled at Site 536, which may correspond to the upper part of Unit J1. A broad de- pression trending north-south also formed during the later part of J1 time (Fig. 3). The western margin of this trough may represent relief on an east-facing shelf margin, since the seismic surveys indicate a broad undeformed platform in the entire southwestern part of the area (Figs. 3 and 4 ).

After deposition and deformation of the J1 unit, there was a broad marine transgression into the area. This probably took place in the Late Jurassic along with the transgression of the Gulf basin to the north. Marine deposits are inferred for $\mathrm{J} 2$ from the seismic similarity to the drilled Early Cretaceous sequences above. Low-relief shelf margins in the area, interpreted from the seismic data, suggest that shallow-water carbonate platforms were present that graded laterally into slightly deeper marine basins. These margins probably were controlled by paleotopography on the underlying, deformed $\mathrm{J} 1$ unit. In some places the $\mathrm{J} 2$ unit, too, is deformed, indicating that movement of some blocks continued into the Late Jurassic. Before the end of the Jurassic, therefore, a 
Table 1. Major seismic subdivisions, southeastern Gulf of Mexico.

\begin{tabular}{|c|c|c|c|c|}
\hline Unit & Age & $\begin{array}{l}\text { Seismic facies and } \\
\text { regional variation }\end{array}$ & Equivalent in borehole & Interpretation \\
\hline KC & $\begin{array}{l}\text { Late Cretaceous-Cenozoic } \\
\text { on basis of DSDP Holes } \\
97,536,537,538 A \text {, and } \\
540\end{array}$ & $\begin{array}{l}\text { In the south, the lower part (Cretaceous- } \\
\text { Eocene) forms thick wedges, coming } \\
\text { from Cuba, characterized by continu- } \\
\text { ous to discontinuous, divergent } \\
\text { facies. Upper part (Eocene-Recent) is } \\
\text { a thin blanket, with many uncon- } \\
\text { formities. Unit thins to north in } \\
\text { drilling area and then thickens again } \\
\text { into Gulf basin farther to the north. } \\
\text { Four mapping units (Table 3). }\end{array}$ & $\begin{array}{l}\text { Drilled thin distal part of unit at } \\
\text { Sites } 540 \text { and } 97 \text {, approxi- } \\
\text { mately } 270 \mathrm{~m} \text { of carbonate } \\
\text { ooze, chalk, and marl. } \\
\text { Lower part disturbed by } \\
\text { creep and slumping. Lower } \\
56 \mathrm{~m} \text { are gravity-flow de- } \\
\text { posits. }\end{array}$ & $\begin{array}{l}\text { Eocene-Recent consists of pelagic } \\
\text { drape in southern and central } \\
\text { part of area. Onlapped by } \\
\text { distal turbidites of Gulf basin } \\
\text { to the north. Cenomanian- } \\
\text { Eocene forms a thick wedge } \\
\text { of turbidites and gravity-flow } \\
\text { deposits in foredeep of Cuban } \\
\text { orogen. Local carbonate } \\
\text { debris shed from Florida } \\
\text { Scarp (Angstadt, 1983). }\end{array}$ \\
\hline EK & $\begin{array}{l}\text { Early Cretaceous on basis } \\
\text { of DSDP Holes } 535, \\
536,537,538 \mathrm{~A} \text {, and } 540\end{array}$ & $\begin{array}{l}\text { Widespread throughout northern and } \\
\text { eastern part of area. Up to } 2 \mathrm{~km} \\
\text { thick. Thickens to east along base of } \\
\text { Florida Escarpment. Thin or absent } \\
\text { to south and west owing to both } \\
\text { nondeposition on high-standing areas } \\
\text { and post-mid-Cretaceous erosion. } \\
\text { Subdivided into several sequences } \\
\text { and four mapping units (Table 2). } \\
\text { Relatively uniform parallel continu- } \\
\text { ous facies over most of the area. } \\
\text { More discontinuous and hummocky } \\
\text { along Florida Escarpment. Promi- } \\
\text { nent N-S hummocky facies in middle } \\
\text { unit. }\end{array}$ & $\begin{array}{l}\text { Drilled almost entire unit in } \\
\text { Holes } 535 \text { and } 540 ; \text { approxi- } \\
\text { mately } 750 \mathrm{~m} \text { of pelagic } \\
\text { limestone-marly limestone } \\
\text { cycles with episodic interbed- } \\
\text { dings of shallow-water lime } \\
\text { sand and mud. Thin equiva- } \\
\text { lents drilled at Holes } 537 \\
\text { and 538A (clastics and } \\
\text { shallow-water limestones } \\
\text { overlain by pelagic lime- } \\
\text { stones) and at Hole } 536 \\
\text { (talus deposits). }\end{array}$ & $\begin{array}{l}\text { Deep-water carbonate deposition } \\
\text { in northern and eastern part } \\
\text { of study area. Main source } \\
\text { was Florida platform to east } \\
\text { and planktonic carbonate } \\
\text { production (Phair, in press). }\end{array}$ \\
\hline J2 & $\begin{array}{l}\text { Probably Late Jurassic on } \\
\text { basis of position below } \\
\text { Earliest Cretaceous } \\
\text { drilled in Hole } 535\end{array}$ & $\begin{array}{l}\text { Uniform, variable-amplitude, continuous } \\
\text { reflections. Widespread over most of } \\
\text { area. Deformed in depressions be- } \\
\text { tween horsts. Absent on high-stand- } \\
\text { ing blocks to west. Slightly deformed } \\
\text { in places owing to later tectonic } \\
\text { movement. }\end{array}$ & Not reached & $\begin{array}{l}\text { Seismic character similar to } \\
\text { Cretaceous above, suggesting } \\
\text { deep-marine deposition in } \\
\text { central part of area. Possible } \\
\text { low-relief shelf margins in } \\
\text { places suggest transition to } \\
\text { shallow-marine around pe- } \\
\text { riphery of area. Probably } \\
\text { represents major marine } \\
\text { transgression and establish- } \\
\text { ment of seaway in area (Phair } \\
\text { and Buffler, 1983). }\end{array}$ \\
\hline J1 & $\begin{array}{l}\text { Inferred to be Jurassic, } \\
\text { possibly Middle Juras- } \\
\text { sic, on basis of superpo- } \\
\text { sition }\end{array}$ & $\begin{array}{l}\text { Widespread unit in south with relatively } \\
\text { uniform thickness (several km) and } \\
\text { seismic character (high-amplitude, } \\
\text { discontinuous). Onlaps broad base- } \\
\text { ment highs. Undeformed in south } \\
\text { except down-dropped along promi- } \\
\text { nent NW-SE graben system and } \\
\text { along broad trough north of Cuba. } \\
\text { To north unit fills half-grabens be- } \\
\text { tween tilted fault blocks. }\end{array}$ & $\begin{array}{l}\text { May have just reached top of } \\
\text { unit in bottom of Hole } 536 \text {. } \\
\text { Shallow-water dolomite, } \\
\text { Jurassic or Permian on basis } \\
\text { of } 87 / 86 \mathrm{Sr} \text { ratio. }\end{array}$ & $\begin{array}{l}\text { Seismic character and setting to } \\
\text { north suggests non-marine } \\
\text { synrift sediments (alluvial } \\
\text { fans, lacustrine deposits, } \\
\text { volcanics, evaporites). Upper } \\
\text { part of unit in south may be } \\
\text { shallow-marine platform. } \\
\text { Lower part to south may be } \\
\text { nonmarine (Phair and Buf- } \\
\text { fler, 1983). }\end{array}$ \\
\hline TJ & $\begin{array}{l}\text { Inferred to be Late Trias- } \\
\text { sic-Early Jurassic on } \\
\text { basis of setting }\end{array}$ & $\begin{array}{l}\text { Southeast-dipping parallel reflections } \\
\text { filling NE-SW-trending graben } \\
\text { system. Onlaps basement. Truncated } \\
\text { by prominent unconformity. }\end{array}$ & Not reached & $\begin{array}{l}\text { Inferred to represent equivalent } \\
\text { of Late Triassic-Early Jurassic } \\
\text { rift sequences observed else- } \\
\text { where around margins of } \\
\text { North Atlantic and Gulf of } \\
\text { Mexico. Probably nonmarine } \\
\text { sediments and volcanics } \\
\text { (Phair and Buffler, 1983). }\end{array}$ \\
\hline Basement & $\begin{array}{l}\text { early Paleozoic ( } 500 \mathrm{Ma}) \\
\text { metamorphic rocks } \\
\text { intruded by early Meso- } \\
\text { zoic }(160-190 \mathrm{Ma}) \text { dikes } \\
\text { and sills }\end{array}$ & $\begin{array}{l}\text { Acoustic basement over much of the } \\
\text { area. In places contains some low- } \\
\text { amplitude reflections. Occurs as } \\
\text { broad uplifts and basins to south and } \\
\text { north. High-relief tilted fault-blocks } \\
\text { in central part of area. }\end{array}$ & $\begin{array}{l}\text { Drilled phyllite in Hole } 537 \text { and } \\
\text { gneiss-amphibolite in Hole } \\
\text { 538A intruded by basic dikes } \\
\text { and sills. }\end{array}$ & $\begin{array}{l}\text { Top of rifted and attenuated } \\
\text { (transitional) crust (Buffler et } \\
\text { al., 1981; Ibrahim et al., } \\
\text { 1981). Probably mostly early } \\
\text { Paleozoic (Pan-Africa) meta- } \\
\text { morphic rocks, possibly with } \\
\text { Paleozoic sedimentary rock in } \\
\text { places. Dissected by Jurassic } \\
\text { intrusives and extrusives. }\end{array}$ \\
\hline
\end{tabular}

deep marine seaway had been established in the southeastern Gulf, a setting that persisted throughout the Early Cretaceous, as discussed next.

\section{Early Cretaceous (EK Sequences)}

This is the first time-interval for which boreholes directly aid seismic interpretation. Sites 535,540 , and, to some extent, 536 can be firmly tied to the seismic stratigraphy of the area. Sites 537 and 538, with condensed sections on high-standing fault blocks, contributed significantly to the interpretation of tectonic movements and the nature of basement.

Throughout the Early Cretaceous, the southeastern Gulf was strongly influenced by the rim of carbonate 


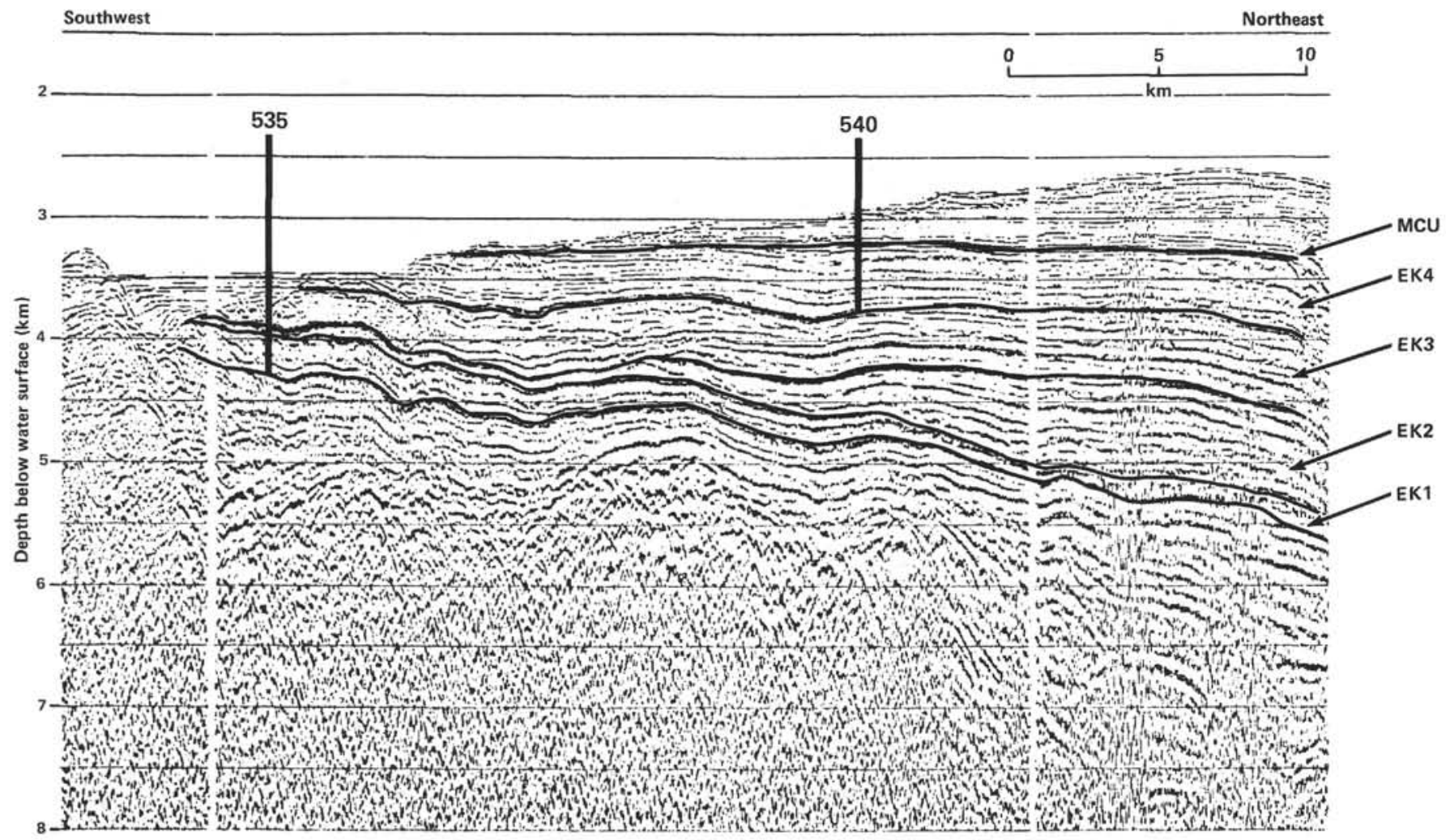

Figure 5. Depth section of seismic Line SF-15, showing Early Cretaceous seismic units EK1-4 near Holes 535 and 540. KC = Late Cretaceous-Cenozoic seismic units.

platforms. The effect on basin sedimentation increased as the platforms rose higher and their slopes steepened. Seismic sequences of the Berriasian-Hauterivian interval vary little in thickness throughout the area, and correspond to purely pelagic limestones with slow rates of deposition at Site 535. From late Hauterivian on, the increasing sediment input from the rapidly rising Florida platform is evident (compare Fig. 6 with Figs. 7 and 8). Seismic units thicken toward the Florida Escarpment, and more shallow-water debris appears in the cores. Similar but narrower tongues of talus rim the Campeche Escarpment, and were drilled at Site 536.

The high sediment input from the platforms, clearly seen in the geometry of seismic sequences, reached the basin Sites 535 and 540 only episodically. Material deposited at these sites was predominantly pelagic carbonate, showing a very persistent alternation of dark, laminated layers rich in organic matter with light, bioturbated layers rich in carbonate. Similar cycles characterize the coeval deposition in the Atlantic (Arthur and Natland, 1979). Cotillon and Rio (this volume) relate the cycles at Sites 535 and 540 to climatic variations driven by the Earth's orbital perturbations.

Sites 537 and 538 on fault blocks in the western part of the study area serve only indirectly as calibration points for the seismic grid. They record a Berriasian transgression on basement, confirming the conclusions, from seismics, that the western portions of the southeastern Gulf stood high during the Jurassic-Early Cretaceous and that thick deep-water sections were confined to a $100-\mathrm{km}$ wide seaway in the center (Figs. 6 and 7).
Sites 537 and 538 present one of the most controversial sedimentologic problems of Leg 77: the depositional environment of the Early Cretaceous limestones. We will briefly review this topic because it bears on the timing of block faulting and the relation of the basement sites to the Yucatan platform. In the site chapters, it was left undecided whether the Berriasian-Valanginian limestones were platform talus, in situ limestone caps (atolls), or faulted parts of a much larger Cretaceous carbonate platform.

The fundamental question is whether the limestones are neritic platform deposits or platform talus shed into deep water (Fig. 17). Compared with those at Site 536, which we consider proven talus, the limestones at Sites 537 and 538 lack almost all features that supported the talus interpretation at 536 . We observed no interbeds of pelagic chalk, no pelagic internal sediment in neritic material, no talus texture. We did find plankton-that is, calpionellids and globigerinids-mixed with the neritic biota. However, there are several well-documented examples of the association of calpionellids and neritic benthos in open-marine shallow-water limestones (Bloxsom, 1972; Baudrimont and Cussey, 1977; Finneran et al., 1982). At Site 536, the setting at the foot of Campeche Bank is a strong argument for the interpretation as talus (see site chapter, Site 536, this volume). At Sites 537 and 538, the setting argues against the talus hypothesis because there is no evidence for Neocomian platforms nearby. Furthermore, the platforms that did exist had a rather modest relief and shed little talus, quite in contrast to their Aptian-Albian counterparts. The simi- 


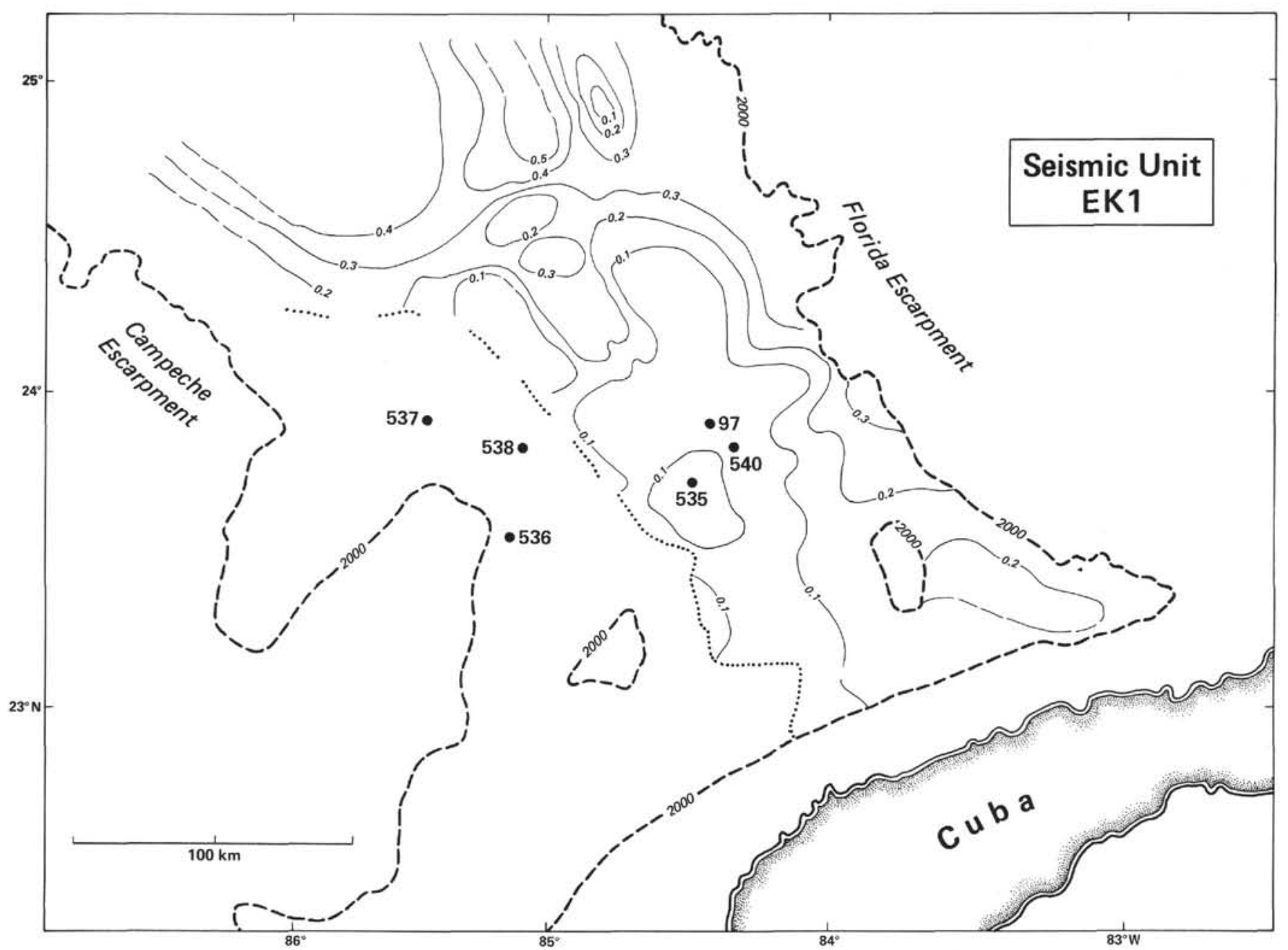

Figure 6. Isochron map of Early Cretaceous seismic unit EK1 (two-way traveltime in seconds). Water depth in meters (heavy lines).

larity to Site 536, in terms of drilling rate and low recovery, is also no argument for talus. DSDP teams on the Challenger had similar recoveries (2-14\%) in genuine platform carbonates (e.g., Campeche Bank: Worzel, Bryant, et al., 1973; Ita Matai seamount in the Pacific: Heezen, McGregor, et al., 1973). The only remaining argument in favor of talus is the interpretation of certain benthic foraminifers in the limestones as bathyal (Sliter and Premoli Silva, this volume). We consider this argument inconclusive because of the uncertainties in the paleo-ecologic interpretation of pre-Tertiary assemblages. Taken overall, the evidence for in situ limestones far outweighs the arguments against it.

The next question is whether these limestones formed two separate, atoll-like caps on high fault blocks or are segments of a larger platform faulted after deposition. The sequence at Site 537 supports the latter interpretation. The section consists of an Early Cretaceous succession of alluvial clastics, littoral clastics and dolomites, and neritic limestones. There is a mismatch in composition between the basement (i.e., phyllite) and the overlying clastics, which are derived from acidic igneous rocks (see site chapter, Site 537, and McBride, both in this volume). Thus, at the time of transgression, the site was still part of a larger drainage pattern, not an isolated high as it is now. Because the limestones overlie the clastics with no discernible age difference (see site chapter, Site 537, and Oertli, both this volume), we believe that they, too, were part of a more extensive carbonate platform, not an isolated atoll. At Site 537 this platform developed over a blanket of siliclastics, whereas at Site 538 it has prograded over deep-water chalk. The implications of the platform hypothesis for the question of Cretaceous faulting will be discussed later.

\section{Late Cretaceous Hiatus and Mid-Cretaceous Unconformity (MCU)}

At all DSDP sites in the southeastern Gulf of Mexico, Late Cretaceous sections are very thin or missing. In the basement Holes 536, 537, and 538A, the Late Cretaceous is represented by a few meters of carbonate ooze and volcanic ash with numerous hiatuses, but with generally well preserved calcareous biota. In the basin Holes 540 and 97 (Worzel, Bryant, et al., 1973), the Cenomanian through early Paleocene sequence is represented by about $50 \mathrm{~m}$ of sediment gravity flows.

We propose a combination of low sediment input, current scouring, and slumping on tectonically steepened 


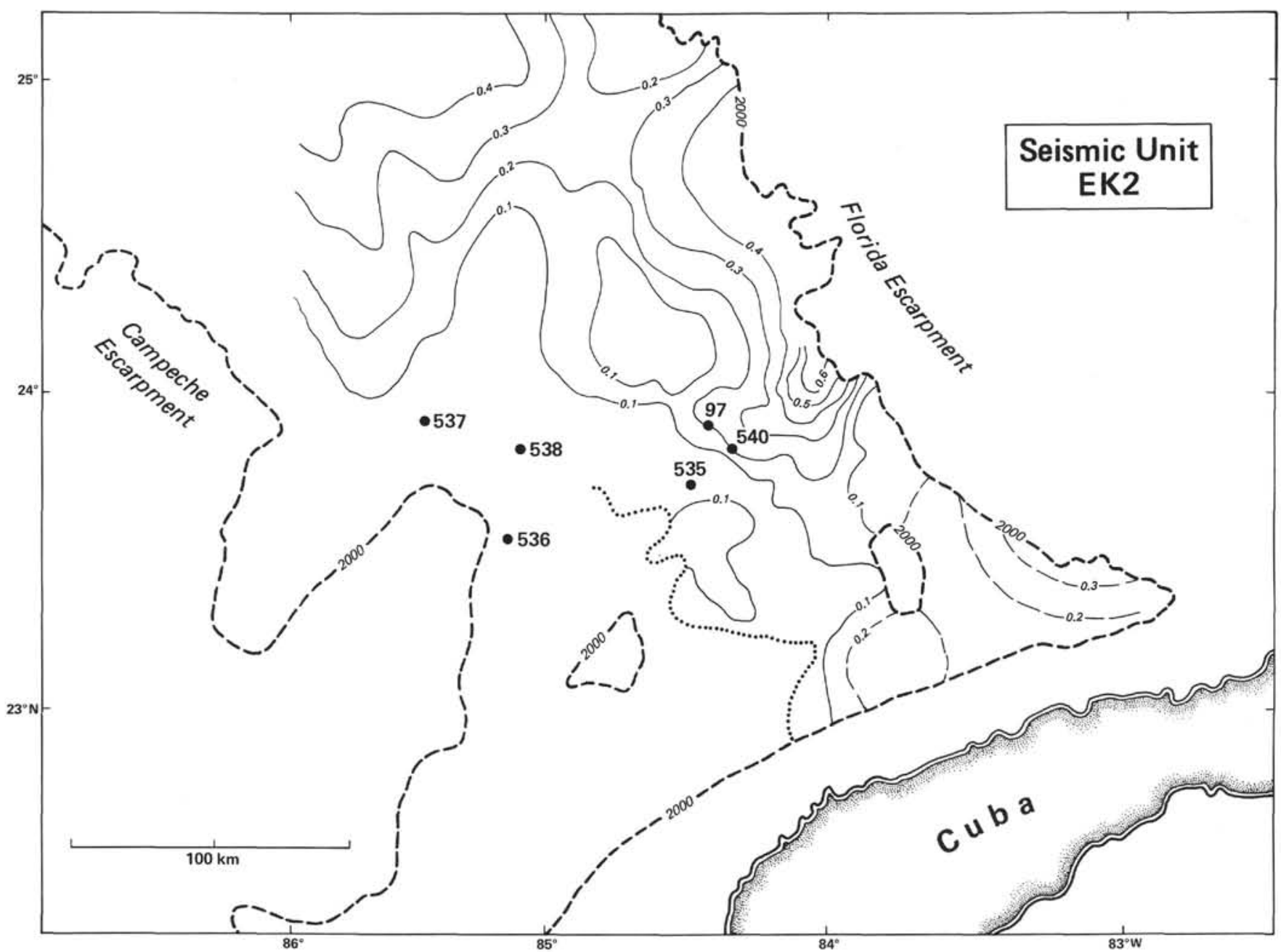

Figure 7. Isochron map of Early Cretaceous seismic unit EK2 (two-way traveltime in seconds). Water depth in meters (heavy dashed lines).

slopes to explain the extreme reduction of the Late Cretaceous section. Sediment input was low because the carbonate platforms rimming the Gulf had been drowned during the Albian-Cenomanian (Arthur and Schlanger, 1979; Schlager, 1981); this greatly reduced the input of shallow-water carbonate. Furthermore, carbonate dissolution at relatively shallow depth may have reduced planktonic carbonate sedimentation in the Aptian through Campanian interval (Thierstein, 1979). Episodic erosion is indicated by hiatuses, hardgrounds, and reworked biota in the holes on basement highs. In these locations, contour currents are a likely mechanism of erosion. A juxtaposition of the Cuban arc approaching from the south and the southern margin of the Bahama-Florida platform as postulated by Malfait and Dinkelman (1972) and Sykes et al. (1982) may have channeled and intensi. fied deep-sea circulation in the area.

The effects of slow sedimentation and current scouring notwithstanding, we feel that tectonics played an important role in reducing the Late Cretaceous section. We think that slopes were tilted and sediment slid off or was eroded through the increased vigor of sediment gravity flows. The record of Site 540 is particularly interesting in this respect. Throughout the middle Albian, the section is practically undisturbed. In the late Albian inter- val we find increasing evidence for creep and slumping: inclined bedding, folds, intraclasts, and occasional mudflows with exotic limestone clasts. Unusually high sediment accumulation rates of $120 \mathrm{~m} / \mathrm{Ma}$ fit well with the lithologic evidence for reworking and slumping. The $\mathrm{Pa}-$ leocene-late Oligocene sequence resembles the late Albian insofar as it also contains slump folds, inclined and wavy layering, and flow structures. The $56 \mathrm{~m}$ of sediment gravity flows between the early Cenomanian and Paleocene horizons contains a normal stratigraphic succession of early or middle Cenomanian, Maestrichtian, and late Paleocene biota. This section can be interpreted either as a complex of mudflows and turbidites emplaced during the Paleogene collision of Cuba and Florida or as a series of Cenomanian through Paleocene sediment gravity flows. In the latter case, tectonic movements or erosion during falls of sea level are possible causes. Further sliding and creep occurred in Eocene-late Oligocene.

An overview of the regional picture, including Cuba and the Cat Gap area in the Atlantic, supports the view of intermittent tectonic activity throughout the AlbianEocene interval. In Cuba, the northern miogeosynclinal belt shows numerous gaps in the Late Cretaceous sections (Pardo, 1975; Pszczolkowski, 1978). At least some of these are angular unconformities (Khudoley and Mey- 


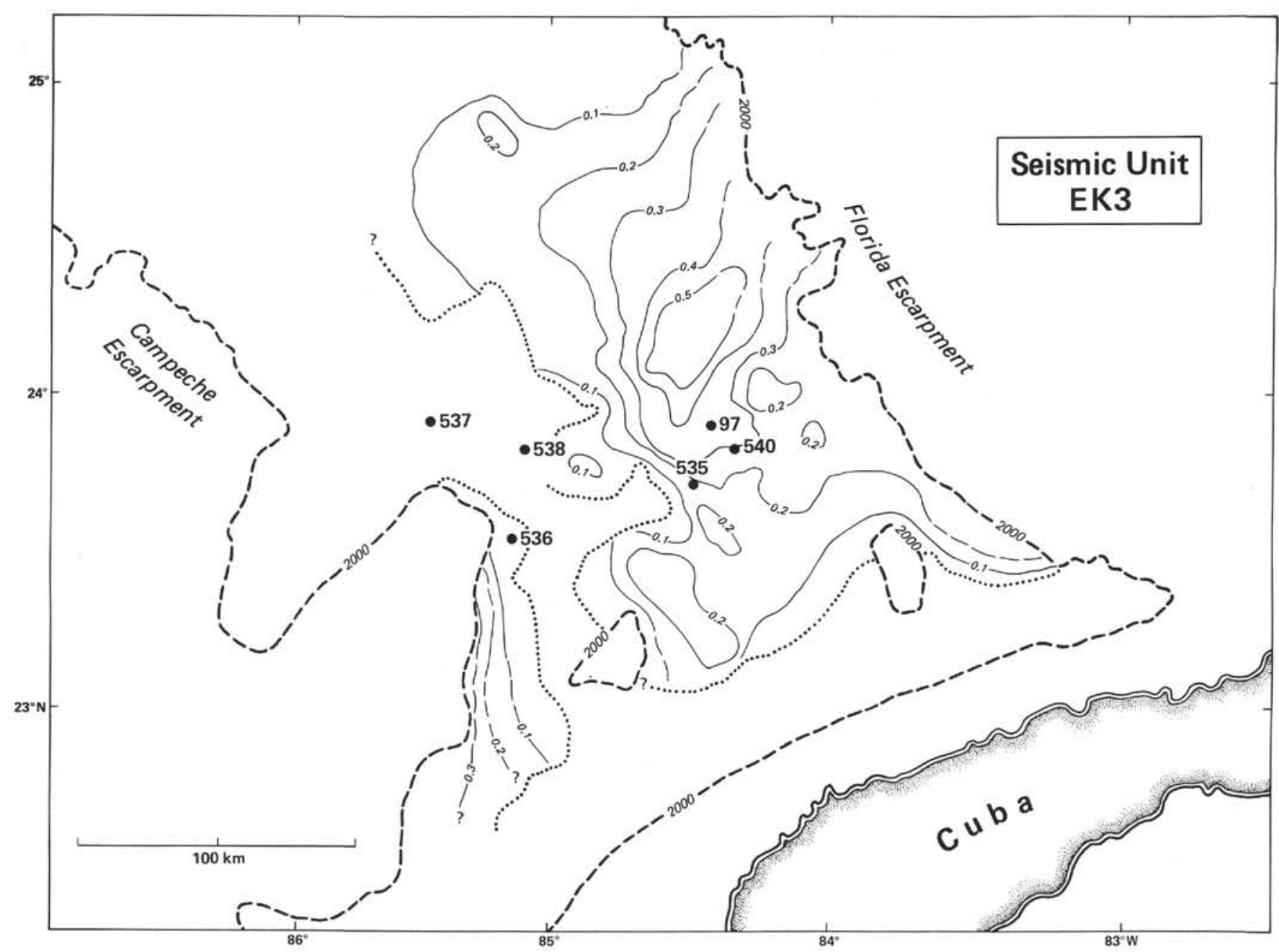

Figure 8. Isochron map of Early Cretaceous seismic unit EK3 (two-way traveltime in seconds). Water depth in meters (heavy dashed lines).

Table 2. Early Cretaceous seismic units, southeastern Gulf of Mexico.

\begin{tabular}{|c|c|c|c|c|}
\hline Unit & Age & $\begin{array}{l}\text { Seismic facies and } \\
\text { regional variation }\end{array}$ & Equivalent in borehole & Interpretation \\
\hline EK4 & $\begin{array}{l}\text { early Cenomanian- } \\
\text { late Albian }\end{array}$ & $\begin{array}{l}\text { Parallel, continuous reflectors of } \\
\text { moderately high amplitude; } \\
\text { toward Florida Escarpment, } \\
\text { reflectors become discontinu- } \\
\text { ous and unit thickens rap- } \\
\text { idly; restricted to eastern } \\
\text { part of study area. }\end{array}$ & $\begin{array}{l}\text { Site } 540: 417 \mathrm{~m} \text { of hemipelagic } \\
\text { limestone-marly limestone cycies } \\
\text { with some shallow-water detritus }\end{array}$ & $\begin{array}{l}\text { EK2-4: Mainly pelagic carbonates in } \\
\text { SW, grading rapidly into hemipe- }\end{array}$ \\
\hline EK3 & $\begin{array}{l}\text { early Albian-late } \\
\text { Albian }\end{array}$ & $\begin{array}{l}\text { Parallel-subparallel, continuous, } \\
\text { of moderate amplitude, } \\
\text { grading westward into hum- } \\
\text { mocky clinoforms, suggest- } \\
\text { ing westward shift of depo- } \\
\text { center with time; absent in } \\
\text { extreme W and largely } \\
\text { eroded near Cuba. }\end{array}$ & $\begin{array}{l}\text { Site } 535: 233 \mathrm{~m} \text { of subdued cycles of } \\
\text { limestone and marly limestone, } \\
\text { frequent interbeds of shallow- } \\
\text { water calcarenites (and mud?). } \\
\text { Equivalent at Site } 536 \text { is plat- } \\
\text { form talus; at } 537 \text { and } 538 \text {, } \\
\text { pelagic chalk and limestone. }\end{array}$ & $\begin{array}{l}\text { lagic deposits with much rede- } \\
\text { posited platform material toward } \\
\text { Florida Escarpment; rates and } \\
\text { loci of platform input changed } \\
\text { with time, creating sequence } \\
\text { boundaries. }\end{array}$ \\
\hline EK2 & $\begin{array}{l}\text { late Aptian-late } \\
\text { Hauterivian } \\
\text { (several hia- } \\
\text { tuses) }\end{array}$ & $\begin{array}{l}\text { Parallel, continuous, and high- } \\
\text { amplitude in SW; changes to } \\
\text { low-amplitude, discontinu- } \\
\text { ous toward Florida Escarp- } \\
\text { ment; rapid thickening in } \\
\text { same direction; thin or } \\
\text { absent in SW. }\end{array}$ & $\begin{array}{l}\text { Site } 535: 80 \mathrm{~m} \text { of cyclic alternation } \\
\text { of pelagic white limestone and } \\
\text { marly limestone rich in organic } \\
\text { matter. Equivalent at Sites } 537 \\
\text { and } 538 \text { is condensed section of } \\
\text { pelagic chalk and limestone. }\end{array}$ & \\
\hline EK1 & $\begin{array}{l}\text { Hauterivian-late } \\
\text { Berriasian }\end{array}$ & $\begin{array}{l}\text { Parallel, continuous, with mod- } \\
\text { erate amplitude; thickens at } \\
\text { foot of northern Florida } \\
\text { Escarpment; thin or absent } \\
\text { in SW; thickness highly } \\
\text { variable in block-faulted } \\
\text { area. }\end{array}$ & $\begin{array}{l}\text { Site } 535: 248 \mathrm{~m} \text { of pelagic limestone } \\
\text { in cyclic alternation with marly } \\
\text { limestone rich in organic matter; } \\
\text { hardgrounds (increasing in fre- } \\
\text { quency downhole). }\end{array}$ & $\begin{array}{l}\text { Mainly pelagic carbonates; minor } \\
\text { sediment contribution from low- } \\
\text { relief platform in NE (Florida); } \\
\text { in W affected by synsedimentary } \\
\text { block faulting. }\end{array}$ \\
\hline
\end{tabular}

Note: Most of this material is after Phair, in press. 


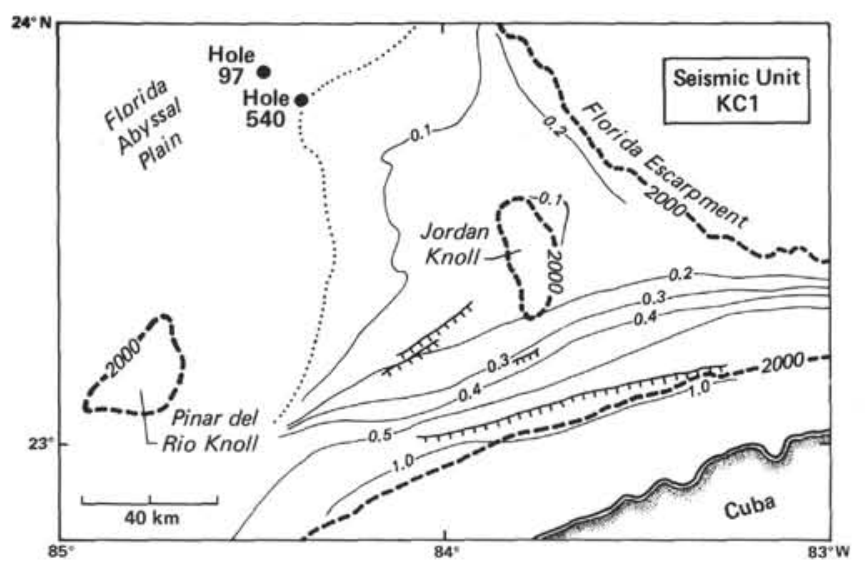

Figure 9. Isochron map of Late Cretaceous-Cenozoic seismic unit $\mathrm{KCl}$ (two-way traveltime in seconds). Water depth in meters (heavy dashed lines).

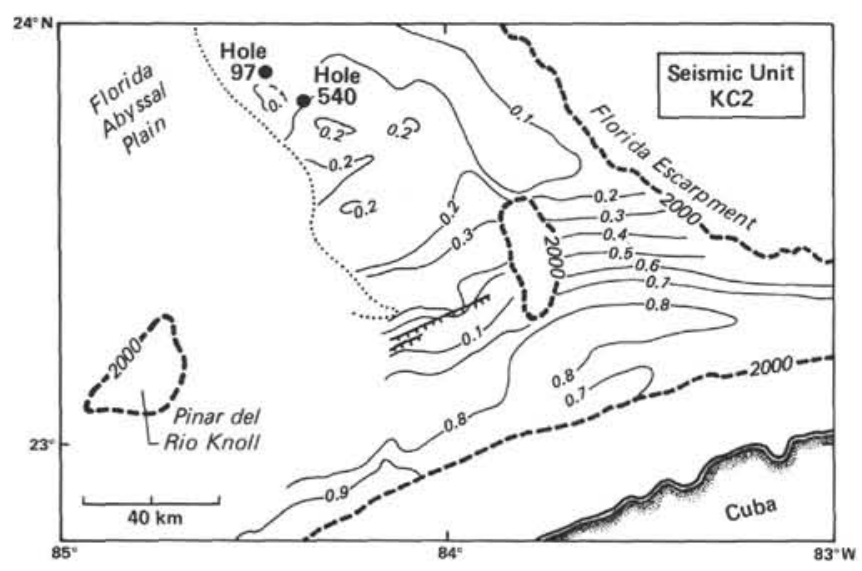

Figure 10. Isochron map of Late Cretaceous-Cenozoic seismic unit $\mathrm{KC} 2$ (two-way traveltime in seconds). Water depth in meters (heavy dashed lines).

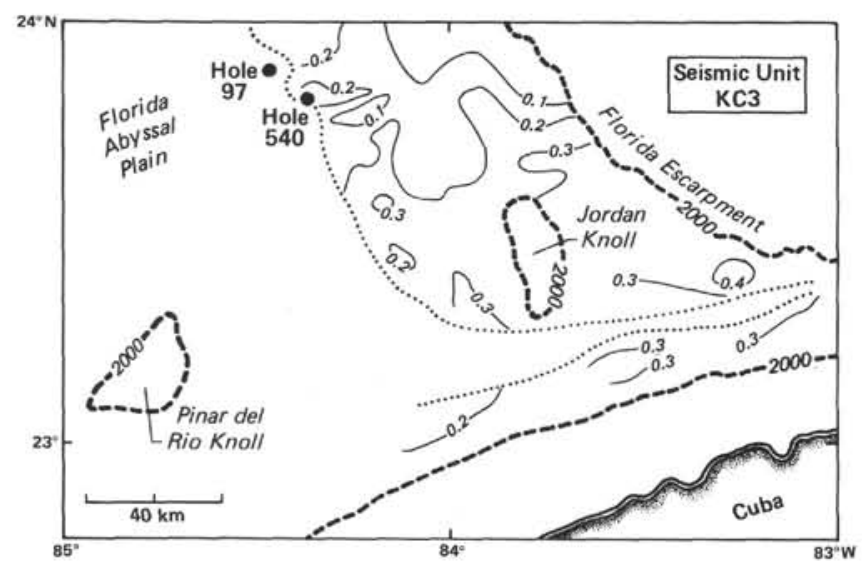

Figure 11. Isochron map of Late Cretaceous-Cenozoic seismic unit KC3 (two-way traveltime in seconds). Water depth in meters (heavy dashed lines).

erhoff, 1971). More or less continuous Albian-Eocene compressional tectonism has been postulated by Shein and others (1978) for Cuba. In the Cat Gap area, east of the Bahamas, Ewing, Worzel, and others (1969) report post-Neocomian tectonic movement. DSDP Holes 4 and
5 (Ewing, Worzel, et al., 1969) and Holes 99, 100, and 101 (Hollister, Ewing, et al., 1972) show stratigraphic gaps in the Albian-Paleogene interval, and reduced Late Cretaceous sections with pebbly mudstones similar to those at Site 540 were recovered at Sites 4 and 5.

The "mid-Cretaceous unconformity" or MCU is a seismo-stratigraphic marker of basin-wide significance in the Gulf of Mexico. Around the margins of the Gulf, it is an unconformity characterized by truncation below and onlap above. In the center of the basin, it becomes a conformity marked by a high-amplitude reflector. It has been traced from DSDP Site 97 throughout the southeastern Gulf of Mexico to the deep western basin (Buffler et al., 1980). In the following we will discuss both timing and origin of this seismic reflector.

The supposition that the reflector is mid-Cretaceous has been tentative from the outset. It was based on the reflector's position very near Cenomanian deep-water sediments at the bottom of DSDP Hole 97, and on a seismic tie to wells in the northeastern Gulf and on Campeche Bank (Buffler et al., 1980; Addy and Buffler, in press). The correlation at Site 97 is weak because the hole has only been spot-cored. Hole 540 , only $9 \mathrm{~km}$ away, penetrated an almost identical seismic section with continuous core recovery, but the correlation remains ambiguous because of the Late Cretaceous hiatus already discussed. The $\mathrm{MCU}$ is also tied to the Campeche and Florida banks, where a strong case can be made for the reflector being mid-Cretaceous (Buffler and others, 1980).

In interpreting the MCU reflector for this chapter, Buffler, Angstadt, and Phair emphasize the role of erosion by deep-sea currents during the Cenomanian lowstand of sea level postulated by Vail and others, 1977. Schlager sees platform drowning during rises of sea level as the prime cause of the MCU. In his opinion, the MCU is a stratigraphic turning point caused by decimation of the carbonate platforms around the Gulf and the concomitant change in sediment input and dispersal. Rapid rises of sea level, possibly coupled with adverse environmental factors, caused a worldwide crisis of platforms in the mid-Cretaceous (Schlager, 1981). During this time, some of the platforms around the Gulf were completely drowned (e.g., Jordan Knoll, Edwards Shelf, Golden Lane) while others were forced to step back to a more landward position (e.g., Campeche and Florida platforms). This drastically reduced sediment input into the Gulf and shifted the loci of deposition to siliciclastic entry points: first, to the Mexican margins in the west (Shaub et al., in press), and later, after the development of the Mississippi drainage, to the northwest and north. We all agree that both erosion and changes in sedimentation occurred in the middle Cretaceous, and that the MCU changes its character throughout the basin. In some places it represents a conformable boundary between carbonate-rich sediments below and carbonatepoor sediments above, in others the onlap of siliclastics on inactive carbonate aprons around the drowned platforms, and in still others an erosional unconformity where the Cretaceous deep-sea carbonates have been dissolved and scoured before the siliciclastics arrived. In the southeastern Gulf, tectonic décollement and slumping, along 


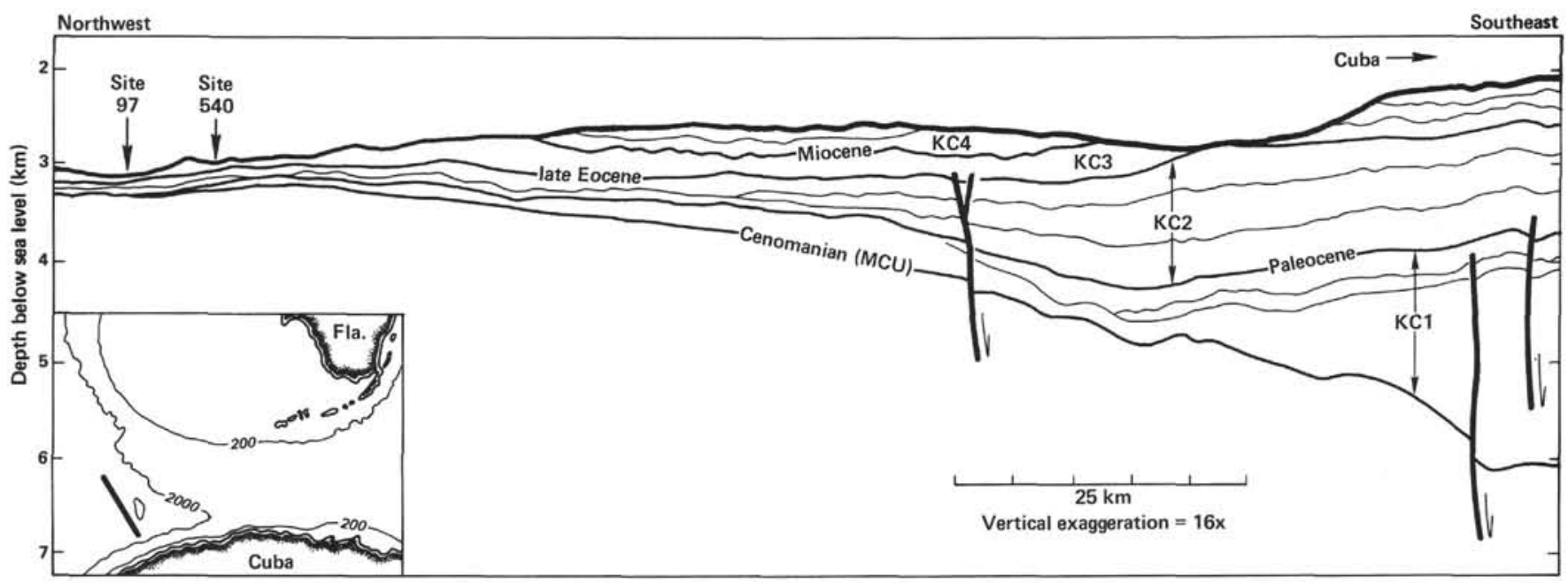

Figure 12. Regional northwest-southeast cross-section (heavy bar on inset map) based on depth-converted seismic profiles. Note southward thickening of seismic units $\mathrm{KCl}$ and $\mathrm{KC2}$ in the Cuban foredeep and localized erosion in pelagic cover (KC3 and $\mathrm{KC4}$ ).

Table 3. Late Cretaceous-Cenozoic seismic units in southeastern Gulf of Mexico.

\begin{tabular}{|c|c|c|c|c|}
\hline Unit & Age & $\begin{array}{l}\text { Seismic facies and } \\
\text { regional variation }\end{array}$ & Equivalent in Borehole & Interpretation \\
\hline KC4 & Recent-middle Miocene & $\begin{array}{l}\text { Parallel, continuous reflection } \\
\text { with numerous small } \\
\text { unconformities; forms } \\
\text { discontinuous drape. }\end{array}$ & $\begin{array}{l}\text { Site } 540: 52 \mathrm{~m} \text { of calcareous ooze } \\
\text { and chalk }\end{array}$ & $\begin{array}{l}\text { Pelagic drape, partly eroded by } \\
\text { turbidity currents and contour } \\
\text { currents }\end{array}$ \\
\hline KC3 & $\begin{array}{l}\text { early middle Miocene- } \\
\text { late Eocene }\end{array}$ & $\begin{array}{l}\text { Parallel, continuous grading } \\
\text { into discontinuous but not } \\
\text { divergent facies near Cuba; } \\
\text { reflection continuity also } \\
\text { degrading to SW owing to } \\
\text { slumping and valley- } \\
\text { cutting. }\end{array}$ & $\begin{array}{l}\text { Site } 540: 191 \mathrm{~m} \text { of chalk and } \\
\text { marly chalk deformed by } \\
\text { sliding (inclined bedding, } \\
\text { folds, microfaults, deformed } \\
\text { burrows) }\end{array}$ & $\begin{array}{l}\text { Mostly pelagic drape, complicated } \\
\text { by slumping on (tectonically?) } \\
\text { over-steepened slopes }\end{array}$ \\
\hline KC2 & $\begin{array}{l}\text { early late Eocene-late } \\
\text { Paleocene }\end{array}$ & $\begin{array}{l}\text { Diverging, continuous, thick- } \\
\text { ening toward Cuba, hum- } \\
\text { mocky along base of } \\
\text { Florida Escarpment; top } \\
\text { boundary is major uncon- } \\
\text { formity with considerable } \\
\text { relief and consistent trun- } \\
\text { cation. }\end{array}$ & $\begin{array}{l}\text { Site 540: } 29 \mathrm{~m} \text { of alternating } \\
\text { chalk and dark marly lime- } \\
\text { stone, deformed by creep or } \\
\text { slumping. Top boundary } \\
\text { corresponds to late Eocene } \\
\text { hiatus. }\end{array}$ & $\begin{array}{l}\text { Mainly turbidites in the south } \\
\text { (Cuba), increasing pelagic } \\
\text { component to north }\end{array}$ \\
\hline $\mathrm{KCl}$ & $\begin{array}{l}\text { late Paleocene-mid- } \\
\text { Cenomanian }\end{array}$ & $\begin{array}{l}\text { Strongly diverging toward } \\
\text { Cuba, with concomitant } \\
\text { decrease in continuity: } \\
\text { minor thickening and } \\
\text { decrease in continuity } \\
\text { toward Florida Escarp- } \\
\text { ment. }\end{array}$ & $\begin{array}{l}\text { Site } 540 \text { : } 56 \mathrm{~m} \text { of sediment } \\
\text { gravity flows (pebbly chalks } \\
\text { overlain by graded conglom- } \\
\text { erates and sandstones), possi- } \\
\text { bly thin interbeds of hemipe- } \\
\text { lagic limestone. Sedimenta- } \\
\text { tion discontinuous; major } \\
\text { hiatuses. Section represents } \\
\text { only small part of correlative } \\
\text { seismic unit. }\end{array}$ & $\begin{array}{l}\text { Mainly slumps and sediment } \\
\text { gravity-flow shed from Cuba, } \\
\text { with minor source along } \\
\text { Florida Escarpment }\end{array}$ \\
\hline
\end{tabular}

Note: Most of this material is after Angstadt, 1983.

with block faulting, have modified the reflector even further and merged it with younger reflectors, as at Site 540.

\section{Late Cretaceous-Cenozoic (KC Sequence)}

After the MCU turning point, sediment input into the southeastern Gulf was no longer controlled by the Florida and Yucatan carbonate platforms. Instead, sediment was shed mainly from the advancing Cuban island arc during the Late Cretaceous-Eocene interval (KC1 and $\mathrm{KC} 2$, Fig. 12). At mid-Eocene time, the northward thrust of Cuba ceased (Sykes et al., 1982; Pindell and Dewey, 1982). The southern sediment source lost its dominant position, and pelagic sedimentation prevailed.

The filling of the Cuban foredeep during the Late Cretaceous-early Eocene is reflected dramatically in the geometry of the coeval seismic units (Figs. 9, 10, and 12). Thickness of $\mathrm{KC} 1$ increases five-fold between Jordan Knoll and the north slope of Cuba. Isochrons closely parallel the slope, suggesting a line source rather than a single-canyon point-source of sediment gravity flows. Thickening of $\mathrm{KC} 2$ is more gradual, and input is concentrated in the southwest, suggesting a major canyonfan system in this area. Seismic facies indicate a shift from mainly slumps and debris flows in the thickest portion of $\mathrm{KCl}$ to more widely spread turbidites in $\mathrm{KC2}$. In the north, protected by Jordan Knoll, a rapid transition occurs into the predominantly pelagic carbonates cored at Site 540. Other effects of the Cuban orogeny are reverse faults and monoclinal folds along the north slope of Cuba and synsedimentary down-to-south faults in $\mathrm{KC1}$ along the northern flank of the foredeep (Fig. 12). 
The Eocene unconformity on top of $\mathrm{KC} 2$ represents another major change in depositional regime. By that time, Cuba was firmly welded to Florida, and flysch sedimentation in the foredeep had ended (Angstadt et al., 1983). Seismic units KC3 and 4 in the southeastern Gulf are composed of rather evenly spread pelagic deposits modified by erosion and redeposition from contour currents or turbidity currents. Coring in Hole 540 recovered carbonate ooze, marl, and chalk, with hiatuses becoming more abundant upward in the section (Watkins, this volume). A major hiatus between late Oligocene and middle Miocene deposits in Hole 540 corresponds to the boundary of Units KC3 and 4. From late Eocene on, turbidity currents seem to have followed a similar pathway along a northwest- or west-dipping valley with tributaries on the flanks of Cuba and Florida. Erosion in these valleys caused several large slides along their flanks.

\section{Timing of Block Faulting}

Passive-margin evolution calls for intensive block faulting in the rift stage, followed by a drift stage with steady subsidence and only minor rotational movements of the blocks. The southeastern Gulf has not followed this pattern entirely. The boreholes indicate that faulting continued (or was reactivated) throughout Cretaceous and possibly Eocene time, well past even the drift stage of the margins.

A comparison of Sites 537 and 538, located on two horsts $30 \mathrm{~km}$ apart, yields evidence for Early Cretaceous faulting (Fig. 18). We assume Berriasian faulting to account for the different lithologies of this interval in Holes 537 and 538A. Post-Valanginian faulting at Sites 537 and 538 is required to explain their present positions 1500 to $2000 \mathrm{~m}$ above the Cretaceous on the adjacent downthrown blocks. (If one assumes that the Valanginian limestone caps were not part of a larger platform but formed as two separate atolls, post-Valanginian faulting must nonetheless be postulated because there was no recognizable difference in water depths at the two sites in the Valanginian, whereas the present elevations of their Valanginian limestones differ by $228 \mathrm{~m}$.) The post-Valanginian throw along the faults seems to have increased gradually. Sand-size neritic biota scattered throughout the deep-water assemblage (see Sliter and Premoli Silva, this volume) suggests that some turbidity currents swept over these highs as late as Campanian or Maestrichtian. Clay mineralogy indicates intermittent tectonic activity around the margins of the southeastern Gulf during the Barremian-Albian (Debrabant et al., this volume).

Eocene movement is suggested by a slump in Hole 537. A 9-m interval of Paleocene chalk with slump folds and tilted bedding capped by a hardground lies sandwiched between flat-lying Eocene chalks. We believe that tectonic tilting rather than sediment overloading of the slope caused the slump, because the sedimentation at the site was slow and frequently interrupted (hardgrounds), which makes failure as a result of overloading unlikely.

Faulting along the north slope of Cuba seems to have continued into the late Eocene, as suggested by faults cutting seismic units $\mathrm{KCl}$ and 2 in some profiles (Angstadt, 1983).

In summary, we conclude that faulting persisted, at least episodically, until the Paleogene. It may have started during a Jurassic rift stage, been rejuvenated during the Tithonian-Neocomian reorganization of the Gulf, and continued in the Cuban (Laramide) orogeny.

\section{Relations to Florida, Cuba, and Yucatan}

The DSDP sites in the southeastern Gulf are presently surrounded by three land masses whose relations to one another and to the Gulf of Mexico are a matter of considerable debate. The results of Leg 77, along with the extensive seismic surveys and new literature, lead to certain correlations which we will present and discuss in the following section.

\section{Florida vs. Basin Sites}

We contend that Sites 97,535 , and 540 were attached to the Florida carbonate platform from Neocomian time on. This statement is based on the abundance of shallow-water carbonate detritus in the Cretaceous sections of Sites 535 and 540 and on the geometry of the seismic sequences containing this detritus. Invariably, these sequences thicken toward the Florida Escarpment, with internal reflections becoming more irregular and less continuous, suggesting increasing volumes of slumps and debris flows (Figs. 7, 8, and 14).

\section{Camajuani Zone in Cuba vs. Basin Sites}

The stratigraphic sequence at the basin Sites 535 and 540 we interpret as the northwestern extension of the Camajuani Zone (Pszczolkowski, 1982) in central Cuba, which was deformed and uplifted when the Cuban island arc collided with the Florida-Bahama region. Paleogeography, sediment facies, and structure support this correlation (Figs. 19 and 20). Paleogeographically, the basin sites are part of a (Jurassic?)-Cretaceous deep-water area. To the northeast lies a carbonate platform that was drowned in the Albian or Cenomanian; still farther northeast follows the Florida platform, where carbonate deposition persists to this day. A very similar succession of facies belts is observed in central Cuba (Pardo, 1975; Pszczolkowski, 1982): (1) Camajuani Zone, with a continuous deep-water sequence; (2) Cayo Coco Zone (and probably Old Bahama Channel: M. Ball, pers. comm., 1983), with a carbonate platform up to Aptian, overlain by an Albian-Eocene deep-water sequence; and (3) continuous Mesozoic-Cenozoic shallow-water carbonate in the Yaguajay Zone (Fig. 20).

The Cretaceous of the basin sites is lithologically similar to that of the Camajuani (equals Las Villas Zone). Pardo (1975) describes the Tithonian-Turonian in this zone as a well-bedded sequence of limestones with yellow-orange weathering, wavy laminae, and marly shales (probably equivalents of the marls, rich in organic matter, at Sites 535 and 540). Black chert and turbidites with neritic material occur in the Aptian-Turonian interval; there are also hiatuses in the Coniacian through Paleocene, and poorly preserved ammonites are common, much as at Sites 535 and 540. 


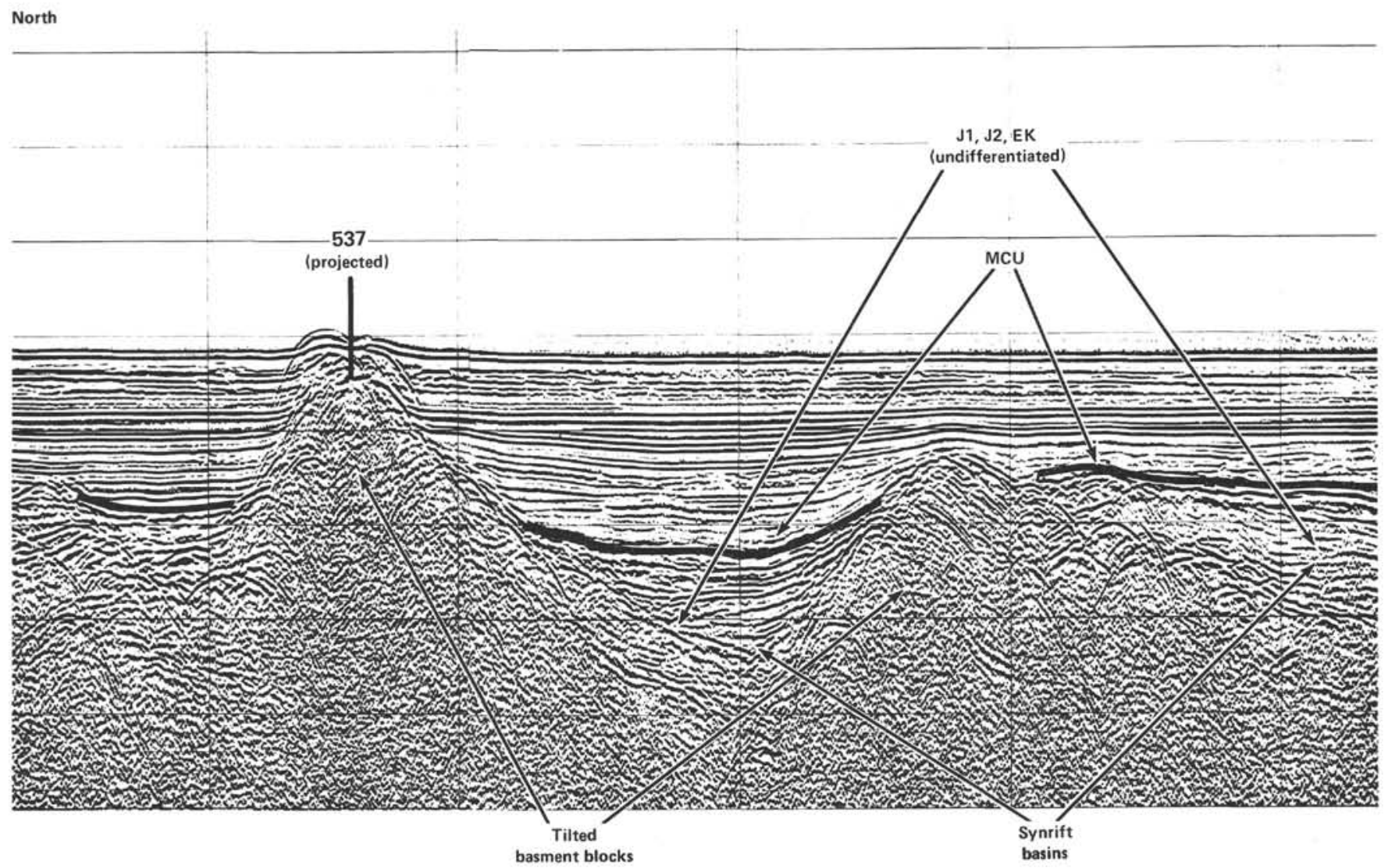

Figure 13. Portions of seismic line GT3-75 near the base of the Campeche Escarpment, showing the regional setting of Sites 536 and 537 . Site 536 is on a large high-standing basement block. Just to the south is a rift basin truncated and onlapped by the J1 unit. To the north is a lower area of fault blocks. Older sedimentary sequences have been tilted and younger basins filled with synrift sediments. Site 537 is on the top of one of the tilted blocks. Drilling there recovered 500( \pm )-Ma-old phyllite.

On the basis of stratigraphy and position in the nappes, Pszczolkowski (1982) correlates the Quinones and the La Esperanza-Rosario zones in western Cuba with the Camajuani Zone and the Placetas Zone, respectively, in central Cuba. This correlation implies that neritic-littoral clastics of the Jurassic Cayetano Group probably underlay the deep-water carbonates of the Camajuani Zone in central Cuba before the sequence was tectonically truncated.

\section{Placetas Zone in Cuba vs. Sites $\mathbf{5 3 7}$ and $\mathbf{5 3 8}$}

An interesting parallel exists between Sites 537 and 538 and central Cuba. The Placetas sequence (Pszczolkowski, 1982; equal to Cifuenetes Belt, Pardo, 1975) resembles Sites 537 and 538 in all major features except the shallow-water limestones, which are absent in Cuba:

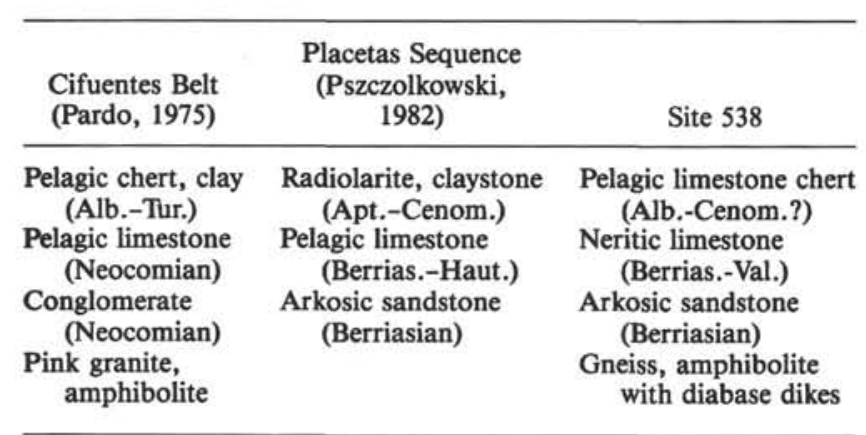

Whether the similarities are coincidental or reflect proximity in space remains open. It should be noted, however, that Sites 537 and 538 lie approximately in the projected extension of the Placetas Zone (Fig. 19).

Basement ages of $61 \mathrm{Ma}$ and $180 \mathrm{Ma}$ have been reported for the Placetas sequence. This is much younger than the $500 \mathrm{Ma}$ ages found at Sites 537 and 538. However, the first date was measured on secondary biotite, and the second date is of questionable validity (Khudoley and Meyerhoff, 1971).

From the above comparison of the basin sites with the Camajuani-Quinones Zone of Cuba, we postulate a Jurassic-Neocomian deep-sea connection between the Gulf of Mexico and the Atlantic south of the Bahamas. If one accepts the north-south succession of zones proposed by Khudoley and Meyerhoff (1971), Pardo (1975), and Pszczolkowski (1982), this seaway consisted of a northern margin of carbonate platforms, passing southward into deep-water carbonates (Camajuani Zone) and, still farther southward, into pelagic shale and chert (Placetas Zone) (Figs. 19 and 20). We believe this seaway connected with the Atlantic either across the southeastern Bahamas (Schlager et al., 1984) or even south of them. Florida and the northwestern Bahama Banks were welded into a single carbonate platform until mid-Cretaceous time, as indicated by widespread Early Cretaceous evaporites and by seismic evidence for shallowwater carbonates in the Straits of Florida and the Provi- 


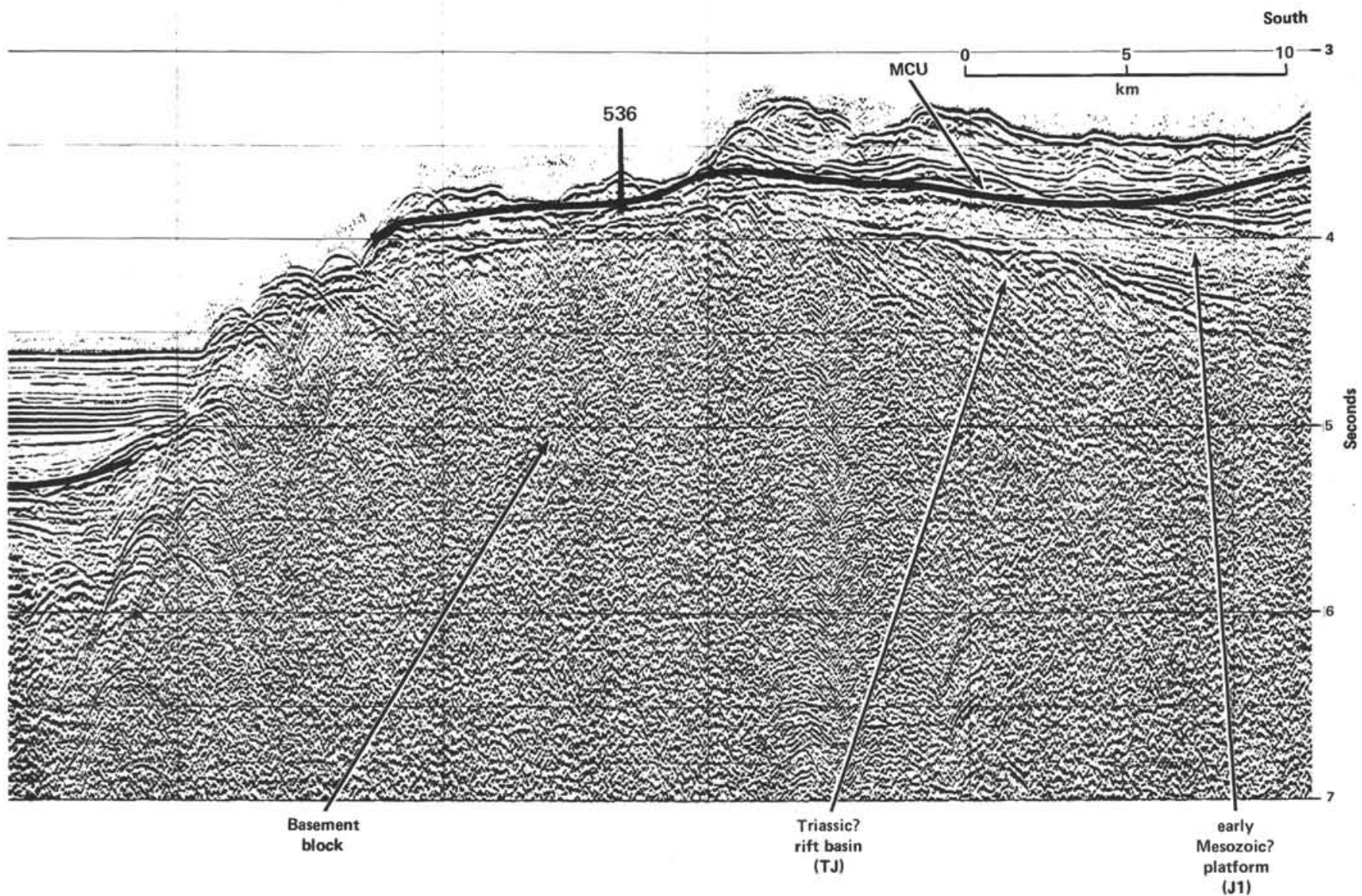

Figure 13. (Continued).

dence Channels (Sheridan et al., 1981; M. Ball, pers. comm., 1983).

\section{Basement of Central Florida vs. Sites $\mathbf{5 3 7}$ and $\mathbf{5 3 8}$}

Sites 537 and 538 belong to the same belt of CambroOrdovician (Pan-African) metamorphics as central Florida (Barnett, 1975; Smith, 1982; Dallmeyer, this volume). This strongly suggests that the area of crustal blocks mapped seismically in the southeastern Gulf is an extension of Florida. No comparable rocks are known from Yucatan, where Silurian granites with late Paleozoic metamorphism have been recovered (Lopez-Ramos, 1975).

The basement affinities between Sites 537 and 538 and northern Florida have important implications for tectonic reconstructions of the regions. One point concerns the transform link between the Jurassic spreading centers in the Atlantic and the Gulf of Mexico (Buffler et al., 1980; Klitgord et al., in press). To us it seems unlikely that the cumulative offset along transform faults in south Florida is as much as $550 \mathrm{~km}$ or that the Blake Spur Anomaly occurs on the west Florida Shelf, as indicated by Klitgord et al. (in press). We suggest instead that the connection between the thinned continental crust in the southeastern Gulf and in southern Florida was never completely severed, and that the offset along the transforms that cut through this crust remained less than 100 to $150 \mathrm{~km}$. If a major offset occurred, it had to be southwest of Sites 537 and 538 ("Campeche Fracture Zone" of Klitgord et al., in press).

\section{Yucatan Platform vs. Site 536}

Possibly since the Jurassic, but certainly since Aptian time, the block on which Site 536 is situated was attached to the Yucatan platform. Evidence of Jurassic attachment is provided by the discovery of shallow-water dolomite, probably Jurassic, beneath the talus at Site 536 (see site chapter), and by seismic evidence in the vicinity of Site 536 for a pre-Cretaceous carbonate platform that underlies the platform talus and has an eastfacing margin. Cretaceous attachment is proven by a combination of core lithology ( $200 \mathrm{~m}$ of Aptian-Albian coarse platform talus) and seismic stratigraphy, which shows that the talus unit wedges out away from the Yucatan-Campeche platform. Despite the foregoing evidence, we cannot rule out the possibility that the present, east-facing segment of the Campeche Escarpment follows a fault trend. This fault, if present, did not obscure the original stratigraphic relationship between platform and talus, however (see also Martin and Case, 1975).

\section{Yucatan vs. Sites 537 and 538}

We believe that since Early Cretaceous time, Sites 537 and 538 were also attached to the Yucatan platform. We have already pointed out that the Berriasian-Valangini- 


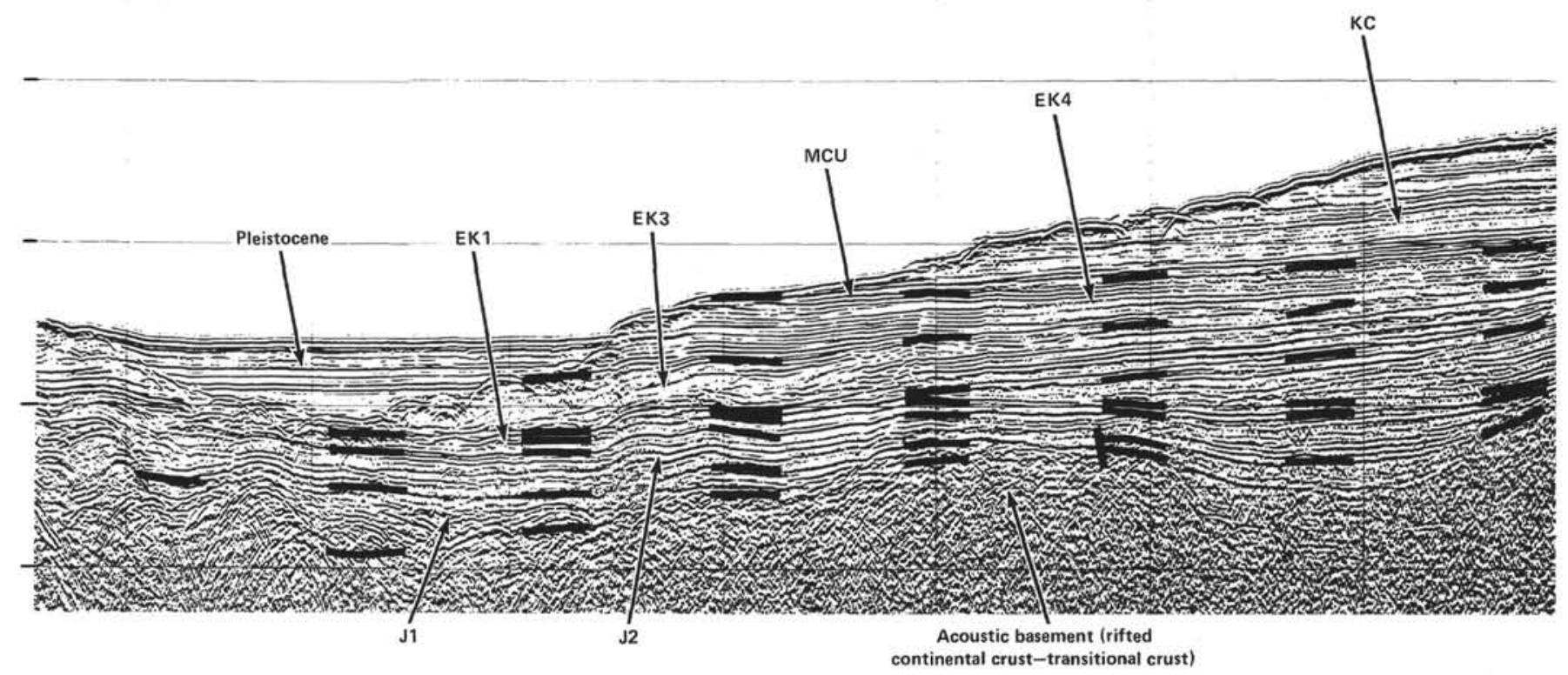

Figure 14. Portions of regional seismic Line SF-4 showing MCU, Early Cretaceous, and Jurassic units overlying basement. Prominent wedge of sediments along base may correlate with MCU.

an limestones at Sites 537 and 538 probably form parts of a much larger carbonate platform. Evidence for this platform is seen on seismic lines in an area northwest of the sites and northeast of the Campeche Escarpment. We consider it the underpinning of the higher but less extensive Aptian-Albian platform (Fig. 17).

\section{Stratigraphy Below Hole 535}

The connection between the Camajuani Zone and the basin sites allows one to use the sections exposed on $\mathrm{Cu}$ ba to complement the borehole stratigraphy. We propose as a working hypothesis that the well-layered seismic stratigraphic units between 4300 and $5000 \mathrm{~m}$ at Site 535 (Fig. 5) are equivalent to the Late Jurassic deep-water limestones in western Cuba. In the Rosario Zones, this sequence-the Artemisa Formation-has recently been described in detail by Pszczolkowski (1978). It consists of 700 to $800 \mathrm{~m}$ of Oxfordian-Hauterivian micritic limestones with pelagic fauna (ammonites, tintinnids, and planktonic foraminifers) and (turbiditic?) interbeds of neritic carbonate material. The deep-water Artemisa Formation grades downward into the mainly neritic Jagua and Francisco formations (shale, with sandstone and limestone; Oxfordian), underlain by the shallow-water clastics of the Cayetano Formation (Middle and Early Jurassic). The more discontinuous and more steeply dipping reflectors below $5200 \mathrm{~m}$ in Figure 5 may be equivalents of the Cayetano clastics, which are considered by some to underlie unconformably the Late Juras- sic formations in western Cuba (Khudoley in Khudoley and Meyerhoff, 1971).

\section{Comparison with North Atlantic}

Most tectonic reconstructions assume a close connection between the Mesozoic North Atlantic and the Gulf of Mexico (e.g., Buffler et al., 1980, 1981; Klitgord et al., in press). Thus, it is instructive to compare the sedimentary sequences in the southeastern Gulf, notably at Sites 535 and 540, with the well-documented central North Atlantic. Formally named formations have been established in the North Atlantic, and have been correlated over vast areas (Jansa et al., 1979; Tucholke and Mountain, 1979). The similarity between Gulf and Atlantic sites is greatest in the Neocomian interval. The two basins followed different lithologic trends from then on.

From the Berriasian through Barremian, the limestone-shale cycles of the Blake-Bahama Formation are closely matched by the limestone-marl cycles of the same interval at Site 535 , both reflecting rhythmic alternation of aerobic and anaerobic bottom conditions, probably coupled with variations in carbonate accumulation. Early Cretaceous sedimentation in the southeastern Gulf was more calcareous than in the North Atlantic, and the terrigenous component was reduced to a background of clay. We attribute this largely to a difference in hinterland. In the Gulf, the rim of carbonate platforms was nearly continuous (e.g., Bryant et al., 1969), whereas in the Atlantic this belt seems to have been breached by av- 

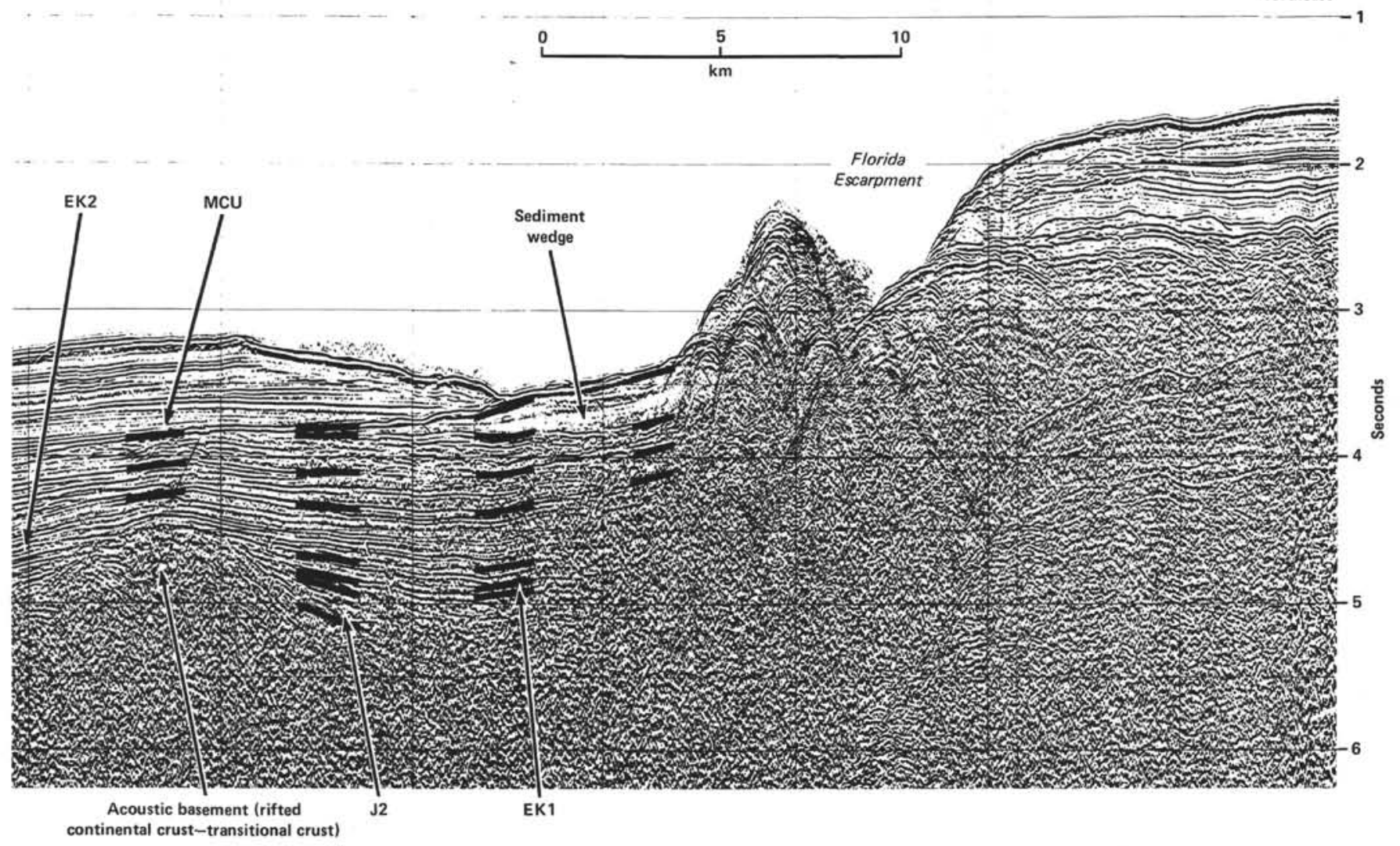

Figure 14. (Continued).

enues of major clastic influx, for instance, off Morocco (Lancelot, Winterer, et al., 1980) and in the northern part of the North American margin (Jansa et al., 1979).

A drastic difference of facies is apparent in the Barremian-Cenomanian interval, which juxtaposes carbonaceous shale of the Atlantic Hatteras Formation and thick limestones at Sites 535 and 540. Like the black Hatteras Shale, the mostly laminated carbonaceous limestones at Sites 535 and 540 indicate predominantly anaerobic conditions. However, most of the Atlantic sites lay below the CCD, whereas the Gulf sites were at least intermittently above it. The facies succession in central Cuba suggests that the deep-water limestones of the Camajuani Zone pass southward into a deeper basin with dark shale and chert (Placetas Zone, Pszczolkowski, 1982). The Placetas rocks may be a better facies equivalent of the Hatteras Shale than the limestones of Sites 535 and 540 (Fig. 20).

During the Cenomanian-Paleocene, low productivity and shallow position of the CCD led to widespread deposition of pelagic clays in the western North Atlantic (Plantagenet Formation, Jansa et al., 1979). In contrast, the southeastern Gulf of Mexico was clearly above the level of intensive carbonate dissolution, as indicated by carbonate ooze with very well preserved calcareous nannofossil floras at Sites 537 and 538 and by equally well preserved Campanian nannofossil floras that were found reworked in Pleistocene mud at Site 535. Thierstein (1979) shows for the Turonian-early Campanian in the North Atlantic a sharp decrease in carbonate content, indicating the onset of intensive dissolution as shallow as $\mathbf{2 0 0 0}$ to $2500 \mathrm{~m}$. Thus, either the sites in the Gulf were situated at a depth of $2000 \mathrm{~m}$ or less during the Late Cretaceous or the Cretaceous Gulf of Mexico was distinctly more saturated with carbonate than the adjacent North Atlantic. Benthic foraminifers provide evidence to support the first interpretation (Sliter and Premoli Silva, this volume).

The early and middle Eocene in the North Atlantic was characterized by abundance of siliceous plankton (mainly radiolarians) and chert (Bermuda Rise Formation). In the southeastern Gulf, we notice a "silica spike" in the same interval, but it is less prominent. At Site 540 , occasional chert nodules appear in marly chalks that otherwise differ little from overlying and underlying beds. At Site 538, the middle Eocene sediments contain layers of radiolarian mudstone in chalk. Nowhere are the siliceous lithologies prominent enough to establish a separate unit for them.

Most of the Tertiary in the western North Atlantic is represented by hemipelagic muds, strongly reworked and redistributed by contour currents (Blake Ridge Formation, Jansa et al., 1979). In the southeastern Gulf, on the other hand, marly carbonate ooze prevailed until the fringes of the Mississippi fan reached the area in the Pleistocene.

\section{Implications for Tectonic Models of the Gulf of Mexico}

The geologic history we have outlined here needs to be compared with existing tectonic models for the early evolution of the Gulf of Mexico. Most current models 

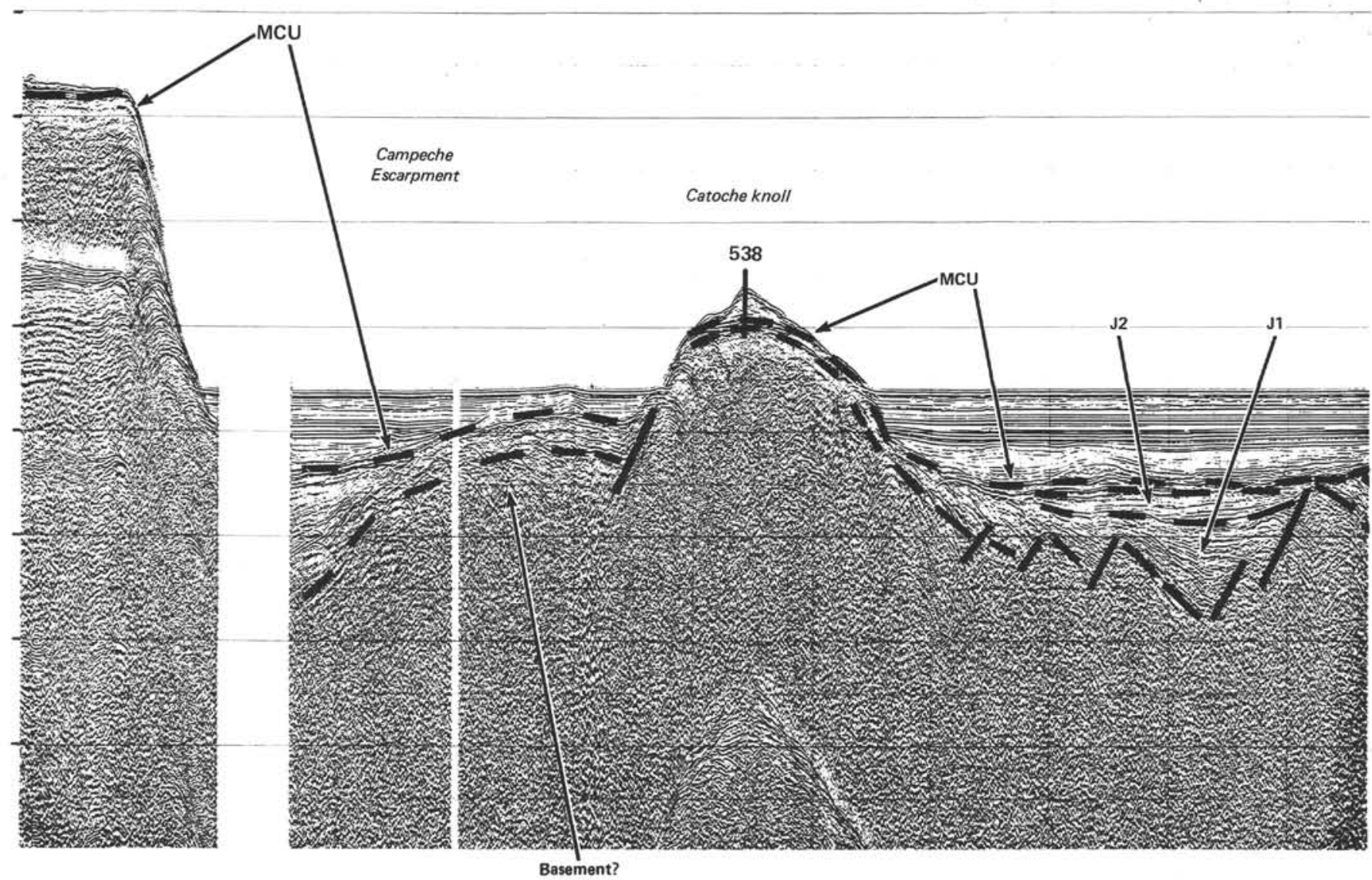

Figure 15. Line SF-2 crosses the area of block-faulted basement. The graben east of Catoche Knoll is floored with a faulted and deformed Middle Jurassic(?) sequence (J1) capped by largely undeformed Late Jurassic fill, J2. Note reversal in the sense of block rotation in the middle of the area. The easternmost block is more rounded and is flanked to the east by a thickening wedge of slightly deformed $\mathrm{J} 2$ sediments showing either incipient diapir-related turtle structure (salt) or drag-folding by transcurrent faulting. Sequences $\mathrm{J} 2$ and EK onlap to the west and thicken to the northeast, suggesting an eastern source. The MCU cuts across the Early Cretaceous sequence, with the hiatus increasing to the west.

postulate variations of the following: (1) a Late Triassic-Early Jurassic period of rifting and attenuation of continental crust to form transitional crust resulting from thermal upwelling; (2) a period of seafloor spreading and formation of ocean crust in the central Gulf sometime in the Late Jurassic; and (3) a period of thermal subsidence. Some models assume a movement of Yucatan from west to east along major transform faults (e.g., Buffler et al., 1981; Klitgord et al., in press; Anderson and Schmidt, 1983). Others suggest a clockwise or counterclockwise rotation of Yucatan during opening of the Gulf (Hall et al. [1983] and Pindell and Dewey [1982], respectively; review of earlier concepts in Martin and Case, 1974). In most models the southeastern Gulf is considered as some sort of transform link between the central Gulf of Mexico and the North Atlantic, underlain by either ocean crust (Pindell and Dewey, 1982; Klitgord et al., in press) or transitional crust (Buffler et al., 1981).

The drilling and seismic data presented here bear on these models at several points. First, they confirm the existence of attenuated and basalt-intruded continental crust postulated by the rifting-spreading models. The drilling of early Paleozoic metamorphic rocks intruded by Mesozoic basic dikes and sills in Holes 537 and 538A strongly supports the concept that the tilted blocks are rifted continental basement. The age of the basic dikes (190-160 Ma) and the presence of the early rift basins (TJ sequences) tend to support an early rift history similar to that of the North Atlantic.

Second, although our data support the idea of Triassic-Early Jurassic rifting, they also indicate extensive Cretaceous block faulting that postdates even the spreading stage of the aforementioned models. This requires either a modification of the time frames for rifting and spreading in the Gulf or an intensive tectonic phase after the spreading stage.

Third, we conclude from our data that in the Early Cretaceous Yucatan was locked in its present position relative to Florida and the southeastern Gulf. Early Cretaceous talus wedges are seen on seismic profiles on the northeast and east sides of the Yucatan platform, and there is no seismic evidence for Late Jurassic-Early Cretaceous faults extending from the Campeche Escarpment 

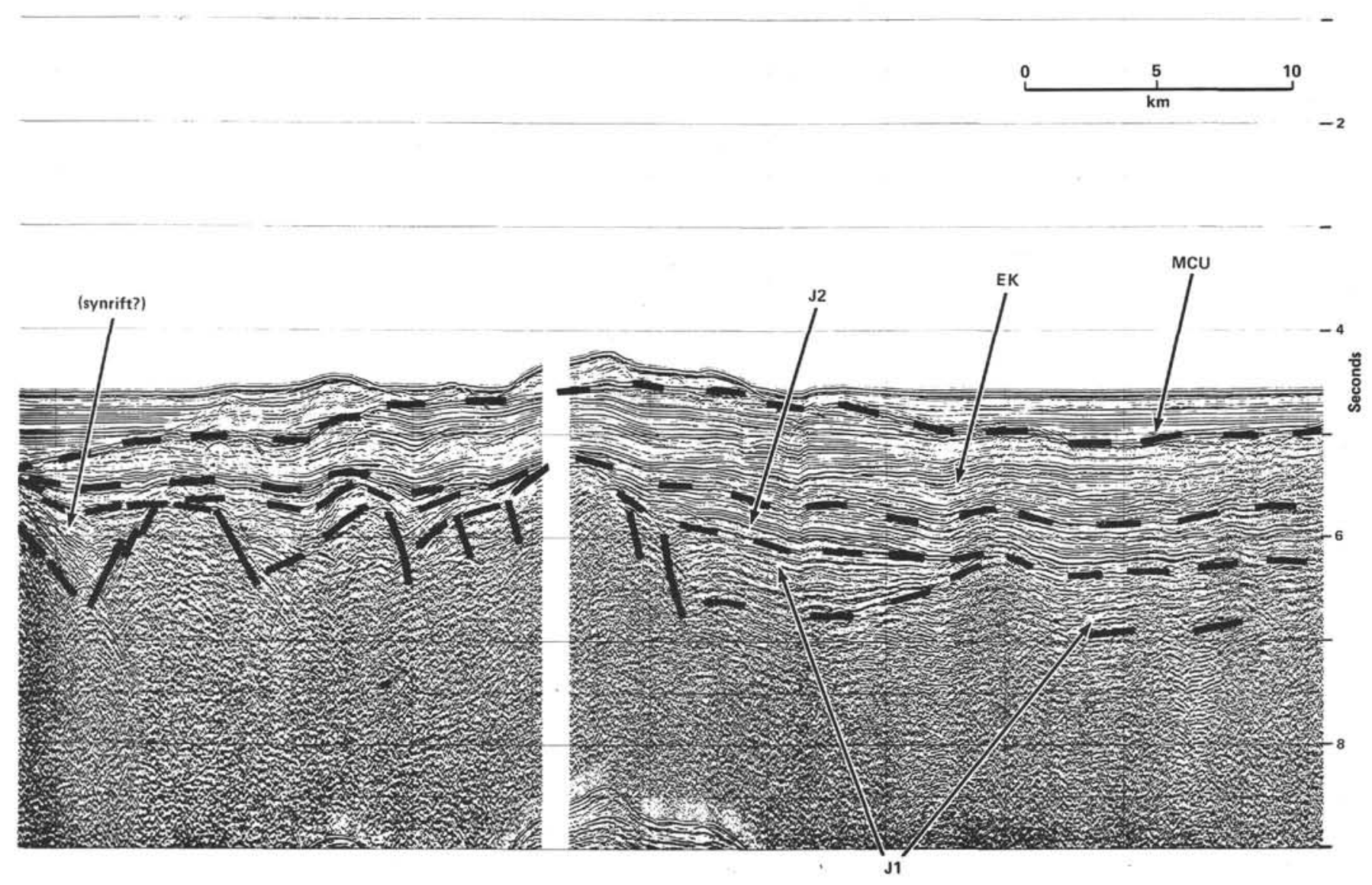

Figure 15. (Continued).

to the east or southeast. Thus, the motions of Yucatan must have occurred in pre-Cretaceous time.

In summary, we favor a model that interprets the southeastern Gulf as a broad transform boundary during the rifting and spreading of the western Gulf basin. There was no complete separation and formation of ocean crust in the area; it is underlain entirely by attenuated continental crust or "transitional" crust. The presently mapped distribution of ocean crust versus transitional crust is compatible with a NNW-to-SSE motion of Yucatan out of the northeastern Gulf, not with a motion from west to east. This movement most likely was accommodated by some component of counterclockwise rotation of Yucatan.

\section{CONCLUSIONS}

1. A combination of seismic stratigraphy and drilling data provides a detailed history of the eastern Gulf of Mexico in the Cretaceous and Cenozoic. The data also present important constraints for the still vaguely known earlier stages of the Gulf.

2. Throughout the Cretaceous and Cenozoic, the southeastern Gulf was a deep seaway between the carbonate platforms of Florida and Yucatan. The structur- al positions of these elements relative to one another remained unchanged throughout this period. Cuba's position relative to the southeastern Gulf became fixed in the late Eocene.

3. Sedimentation in the southeastern Gulf was dominated by input from carbonate platforms during the Early Cretaceous, by input from the advancing Cuban arc from late Cretaceous through late Eocene, and by pelagic carbonate deposition ever since. Widespread seismic unconformities mark the change from one depositional regime to the next: the mid-Cretaceous unconformity correlates with the drowning of carbonate platforms and a period of basin starvation, and the late Eocene unconformity signals the cessation of Cuban tectonics and sediment input from the south. Numerous smaller hiatuses and unconformities indicate minor shifts in sediment input and dispersal.

4. Through their stratigraphy and position seaward of the Florida-Bahama platform, the basin Sites $\mathbf{5 3 5}$ and 540 can be correlated with the Camajuani Zone in central Cuba, whereas the basement Sites 537 and 538 resemble the basement in the Placetas Zone and its Early Cretaceous sediment cover. These correlations suggest a deep seaway connecting the southeastern Gulf, northern 


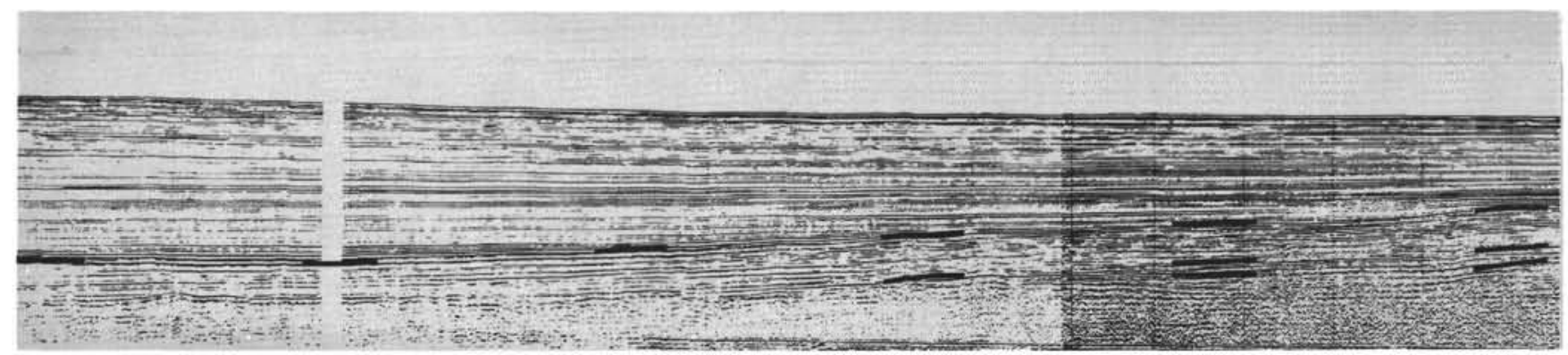

Northwest

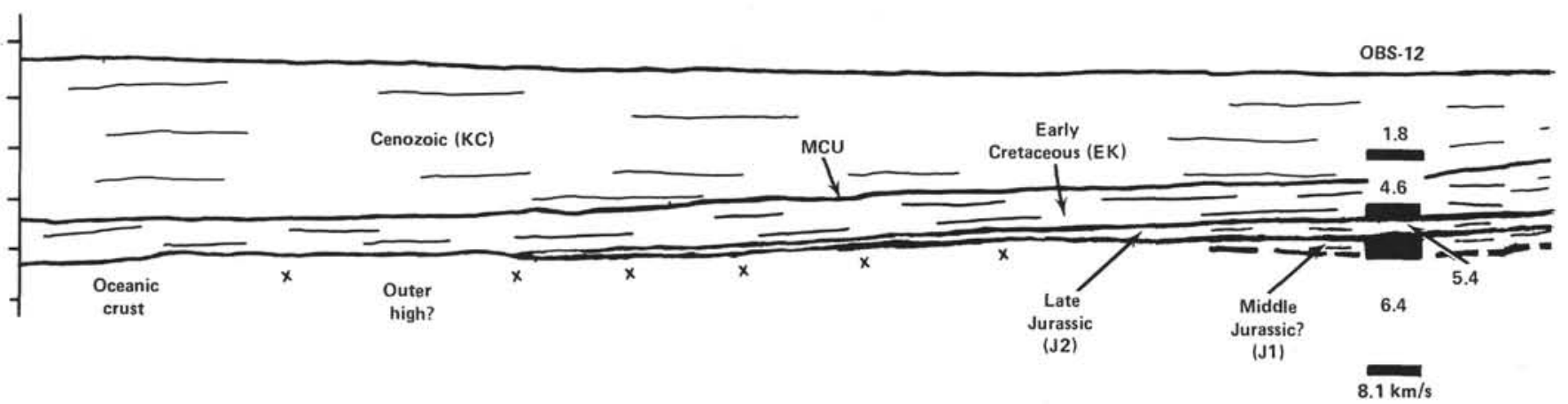

Figure 16. Line GT2-10C crosses southeastern Gulf from northwest to southeast. Note high-standing basement complex to the south and deeper grabens to the north. Basement is overlain by Late Jurassic and Early Cretaceous sediments (drilled in DSDP Holes 535 and 540 ), indicating that this region of the southeastern Gulf was a deep seaway during Late Jurassic-Early Cretaceous. The line also shows the regional change from ocean crust in the northwest to more faulted and higher-standing transitional crust in the southeast. Northward stratigraphic pinchouts of the inferred Middle and Late Jurassic sequences onto the "outer high" (or ocean crust/transitional crust boundary) suggest a relatively young age (possibly latest Jurassic to earliest Cretaceous) for the ocean crust in the southeastern Gulf. OBS-12 is an ocean-bottom seismometer refraction station (Ibrahim et al., 1981).

Cuba, and the central North Atlantic. Atlantic stratigraphy closely resembles that in the southeastern Gulf during Berriasian-Barremian time; later, the sites in the Gulf were shallower and richer in carbonates than most of their counterparts in the central North Atlantic.

5. The pre-Cretaceous history of the area must be inferred from seismic stratigraphy and comparison with the margins of the Gulf of Mexico and the Atlantic. Tilted graben fills on faulted basement may represent Triassic-Early Jurassic rift sediments; up to $2 \mathrm{~km}$ of younger Jurassic sediments are interpreted as an upward succession of alluvial-to-littoral clastics, neritic clastics, and bathyal limestones analogous to the Cayetano, Francisco, and Artemisa formations in western Cuba.

6. Basement consists of attenuated and rifted continental crust (early Paleozoic metamorphics) dissected by Early Jurassic basaltic dikes.

7. With regard to models on the origin of the Gulf of Mexico, our data set several constraints: There is evidence for Triassic-Early Jurassic rifting, but also for much later (Late Jurassic-Cretaceous) block faulting, not explained by the models. The sialic crust in the southeastern Gulf is the same as in Florida, and there is no support for ocean crust along the postulated AtlanticGulf transform link in the area. The offset along the postulated transform faults in southern Florida could not have been more than 100 to $150 \mathrm{~km}$. Yucatan, whose motions play a pivotal role in several models, was locked in place from Early Cretaceous time on.

\section{ACKNOWLEDGMENTS}

Much of what we reported could not have been accomplished without the help of the Scientific Party of Leg 77 and the skilled crews of the Glomar Challenger and the Fred Moore. We thank J. A. Austin and R. Martin for their very helpful and prompt reviews of the manuscript. This work was supported by the Industrial Associates of the University of Texas Institute of Geophysics and the University of Miami Comparative Sedimentology Laboratory. This is University of Texas Institute for Geophysics Contribution Number 589.

\section{REFERENCES}

Addy, S. K., and Buffler, R. T., in press. Seismic stratigraphy of the shelf slope, northeastern Gulf of Mexico. Am. Assoc. Petrol. Geol. Bull.

Anderson, T. H., and Schmidt, V. A., 1983. The evolution of Middle America and the Gulf of Mexico-Caribbean Sea region during Mesozoic time. Geol. Soc. Am. Bull., 94:941-966.

Angstadt, D. M., 1983. Late Cretaceous-Recent seismic stratigraphy and geologic history of the southeastern Gulf of Mexico-southwestern Straits of Florida [M.A. thesis]. University of Texas at Austin.

Angstadt, D. M., Austin, J. A., Jr., and Buffler, R. T., 1983. Deep-sea erosional unconformity in the southeastern Gulf of Mexico. Geology, 11:215-218.

Arthur, M. A., and Natland, J. H., 1979. Carbonaceous sediments in the North and South Atlantic: the role of salinity in stable stratification of Early Cretaceous basins. In Talwani, M., Hay, W. W., and Ryan, W. B. F. (Eds.), Deep Drilling Results in the Atlantic Ocean: Continental Margins and Paleoenvironment: Washington (Am. Geophys. Union), Maurice Ewing Series, 3:375-401.

Arthur, M. A., and Schlanger, S. O., 1979. Cretaceous "oceanic anoxic events" as causal factors in development of reef-reservoired giant oil fields. Am. Assoc. Petrol. Geol. Bull., 63:870-885.

Barnett, R. S., 1975. Basement structure of Florida and its tectonic implications. Trans. Gulf Coast Assoc. Geol. Soc., 25:122-142. 

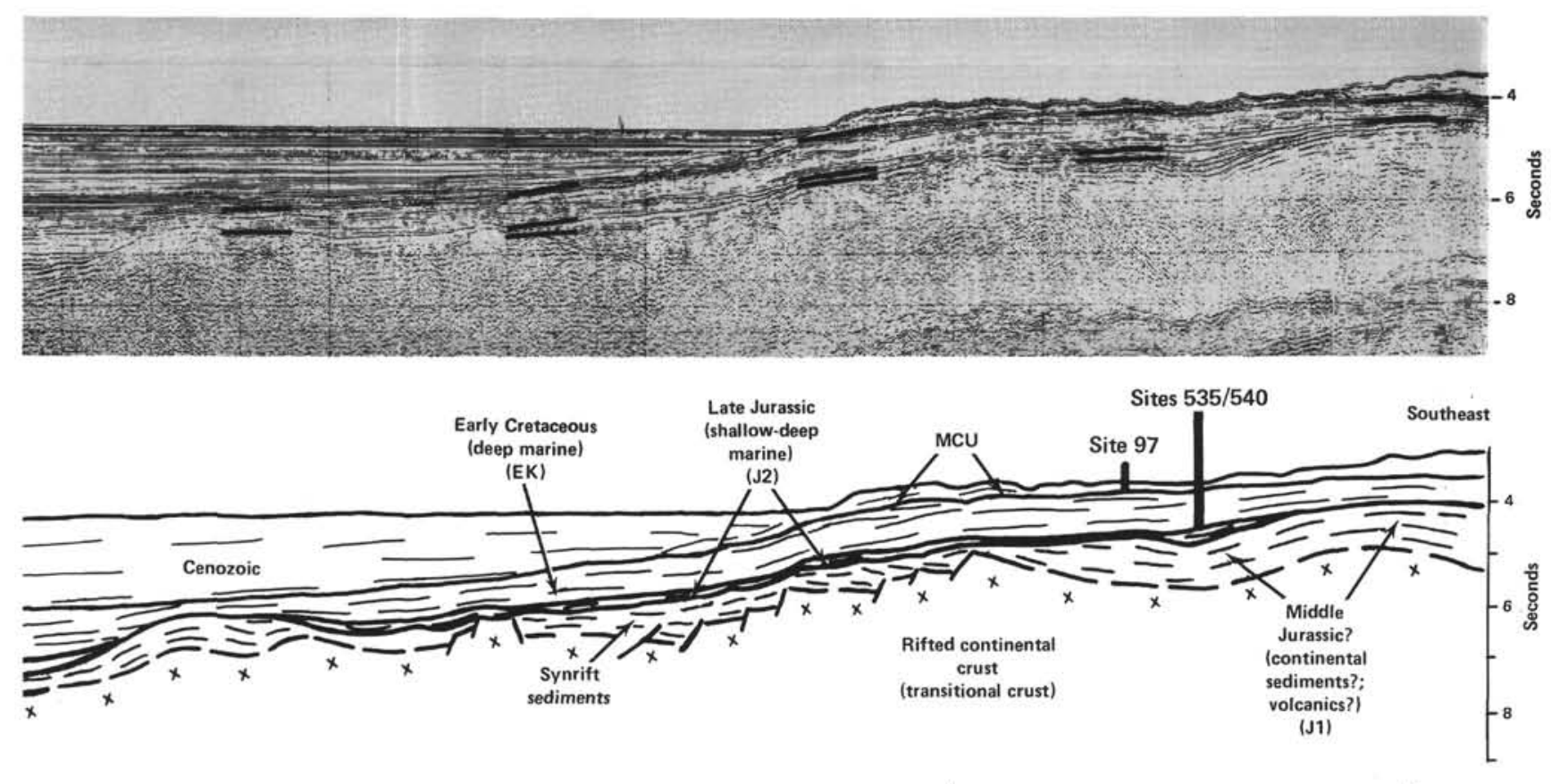

$50 \mathrm{~km}$

Figure 16. (Continued).

Baudrimont, A. F., and Cussey, R., 1977. Sédimentologie du Jurassique de la Bordure Provençale du Bassin du Sud-est (France). In Elf-Aquitaine: Essai de caractérisation sédimentologique des dépôts carbonates. 2. Eléments d'interprétation: Pau (Elf-Aquitaine, Centres de Recherches de Boussens et de Pau), pp. 195-206.

Bloxsom, W. E., 1972. A Lower Cretaceous (Comanchean) prograding shelf and associated environments of deposition, northern Coahuila, Mexico [M.A. thesis]. University of Texas at Austin.

Bryant, W. R., Meyerhoff, A. A., Brown, N. K., Furrer, M. A., Pyle, T. E., and Antoine, J. W., 1969. Escarpments, reef trends, and diapiric structures, eastern Gulf of Mexico. Am. Assoc. Petrol. Geol. Bull., 53:2506-2542.

Buffler, R. T., Shaub, F. J., Huerta, R., Ibrahim, A. B. K., and Watkins, J. S., 1981. A model for the early evolution of the Gulf of Mexico basin. Oceanol. Acta, Proc. 26th Int. Geol. Cong., Geol. Continental Margins Symp., 3:129-136.

Buffler, R. T., Watkins, J. S., Worzel, J. L., and Shaub, F. J., 1980. Structure and early geologic history of the deep central Gulf of Mexico. In Pilger, R. H. (Ed.), The Origin of the Gulf of Mexico and the Early Opening of the Central North Atlantic Ocean: Baton Rouge (Louisiana State University), pp. 3-16.

Ewing, M., Worzel, J. L., et al., 1969. Init. Repts. DSDP, 1: Washington (U.S. Govt. Printing Office).

Finneran, J. M., Scott, R. W., Taylor, G. A., and Anderson, G. H., 1982. Late Jurassic ramp reefs ("Knowles Limestone"), southwest flank of the east Texas Basin. In Bebout, D. (Ed.), The Jurassic of the Gulf Rim, Third Ann. Res. Conf., Gulf Coast Sec., Soc. Econ. Paleontol. Mineral. Prog. and Abstr., pp. 36-44.

Hall, D. J., Cavanaugh, P. D., Watkins, J. S., and McMillan, K. J., 1983. The rotational origin of the Gulf of Mexico based on regional gravity data. In Watkins, J. S., and Drake, C. L. (Eds.), Studies in Continental Margins. Am. Assoc. Petrol. Geol. Mem., 34: 115-126.

Heezen, B. C., MacGregor, I. D., et al., 1973. Init. Repts. DSDP, 20: Washington (U.S. Govt. Printing Office).

Hollister, C. D., Ewing, J. I., et al., 1972. Init. Repts. DSDP, 11: Washington (U.S. Govt. Printing Office).

Ibrahim, A. B. K., Carye, J., Latham, G., and Buffler, R. T., 1981. Crustal structure in the Gulf of Mexico from OBS refraction and multichannel reflection data. Am. Assoc. Petrol. Geol. Bull., 65: 1207-1229.
Jansa, L. F., Enos, P., Tucholke, B. E., Gradstein, F. M., and Sheridan, R. E., 1979. Mesozoic-Cenozoic sedimentary formations of the North American Basin; western North Atlantic. In Talwani, M., Hay, W. W., and Ryan, W. B. F. (Eds.), Deep Drilling Results in the Atlantic Ocean: Continental Margins and Paleoenvironment: Washington (Am. Geophys. Union), Maurice Ewing Series, 3:1-57.

Khudoley, K. M., and Meyerhoff, A. A., 1971. Paleogeography and geological history of greater Antilles. Geol. Soc. Am. Mem., 129: $1-199$.

Klitgord, K. D., Popenoe, P., and Schouten, H., in press. Florida, a Jurassic transform plate boundary. J. Geophys. Res.

Lancelot, Y., Winterer, E. L., et al., 1980. Init. Repts. DSDP, 50: Washington (U.S. Govt. Printing Office).

Lopez-Ramos, E. L., 1975. Geological summary of the Yucatan Peninsula. In Nairn, A. E. M., and Stehli, F. G. (Eds.), The Ocean Basins and Margins (Vol. 3): New York (Plenum Press), 257-282.

Malfait, B. T., and Dinkelman, M. G., 1972. Circum-Caribbean tectonic and igneous activity and the evolution of the Caribbean Plate. Geol. Soc. Am. Bull., 83:251-272.

Martin, R. G., and Case, J. E., 1975. Geophysical studies in the Gulf of Mexico. In Nairn, A. E. M., and Stehli, F. G. (Eds.), The Gulf of Mexico and Caribbean, Ocean Basins and Margins (Vol. 3): New York (Plenum Press), 65-106.

Pardo, G., 1975. Geology of Cuba. In Nairn, A. E. M., and Stehli, F. G. (Eds.), The Gulf of Mexico and Caribbean, Ocean Basins and Margins (Vol. 3): New York (Plenum Press), 553-615.

Phair, R. L., in press. Lower Cretaceous seismic stratigraphy of the southeastern Gulf of Mexico and southwestern Straits of Florida [M.A. thesis]. University of Texas at Austin.

Phair, R. L., and Buffler, R. T., 1983. Pre-middle Cretaceous geologic history of the deep southeastern Gulf of Mexico. In Bally, A. W. (Ed.), Seismic Expressions of Structural Styles-A Picture and Word Atlas: Tulsa (Am. Assoc. Petrol. Geol.), AAPG Studies in Geology, 15(2):2.2.3-141.

Pindell, J., and Dewey, J. F., 1982. Permo-Triassic reconstruction of western Pangea and the evolution of the Gulf of Mexico/Caribbean Region. Tectonics, 1:179-211.

Pszczolkowski, A., 1978. Geosynclinal sequences of the Cordillera de Guaniguanico in western Cuba: their lithostratigraphy, facies development and paleogeography. Acta Geol. Pol., 28:1-93. 
1982. Cretaceous sediments and paleogeography in the western part of the Cuban miogeosyncline. Acta Geol. Pol., 32:135-161.

Schlager, W., 1981. The paradox of drowned reefs and carbonate platforms. Geol. Soc. Am. Bull., 92:197-211.

Schlager, W., Austin, J. A., Jr., Corso, W., McNulty, C. L., Fluegel, E., Renz, O., and Steinmetz, J. C., 1984. Early Cretaceous platform reentrant and escarpment erosion in the Bahamas. Geology, 12:147-150.

Shaub, S. J., Buffler, R. T., and Parsons, J. T, in press. Seismic stratigraphic framework of the deep Gulf of Mexico basin. Am. Assoc. Petrol. Geol. Bull.

Shein, V. S., Ivanov, S. S., Kleshchev, K. A., Khain, V. Y., Marrero, M., and Socorro, R., 1978. Tectonics of Cuba and its shelf. Int. Geol. Rev., 21:540-552.

Sheridan, R. E., Crosby, J. T., Bryan, G. M., and Stoffa, P. L., 1981. Stratigraphy and structure of southern Blake Plateau, northern Florida Straits, and northern Bahama Platform from multichannel seismic reflection data. Am. Assoc. Petrol. Geol. Bull., 65: 2571-2593.

Smith, D. L., 1982. Review of the tectonic history of the Florida Basement. Tectonophysics, 88:1-22.

Sykes, L. R., McCann, W. R., and Kafka, A. L., 1982. Motion of Caribbean Plate during last 7 million years and implications for earlier Cenozoic movements. J. Geophys. Res., 87:10656-10676.

Thierstein, H. R., 1979. Paleoceanographic implication of organic carbon and carbonate distribution in Mesozoic deep-sea sediment. In Talwani, M., Hay, W. W., and Ryan, W. B. F. (Eds.), Deep Drilling Results in the Atlantic Ocean: Continental Margins and Paleoenvironment: Washington (Am. Geophys. Union), Maurice Ewing Series, 3:249-279.

Tucholke, B. E., and Mountain, G. S., 1979. Seismic stratigraphy, lithostratigraphy and paleosedimentation patterns in the North American Basin. In Talwani, M., Hay, W. W., and Ryan, W. B. F. (Eds.), Deep Drilling Results in the Atlantic Ocean: Continental Margins and Paleoenvironment: Washington (Am. Geophys. Union), Maurice Ewing Series, 3:58-85.

Vail, P. R., Mitchum, R. M., Jr., Todd, R. G., Widmier, J. M., Thompson, S., III, Sangree, J. B., Bubb, J. N., and Hatlelid, W. G., 1977. Seismic stratigraphy and global changes of sea level. In Payton, C. E., (Ed.), Seismic Stratigraphy-Applications to $\mathrm{Hy}$ drocarbon Exploration. Am. Assoc. Petrol. Geol. Mem., 26:49-212.

Worzel, J. L., Bryant, W., et al., 1973. Init. Repts. DSDP, 10: Washington (U.S. Govt. Printing Office).

Date of Initial Receipt: November 3, 1983

Date of Acceptance: December 2, 1983
A

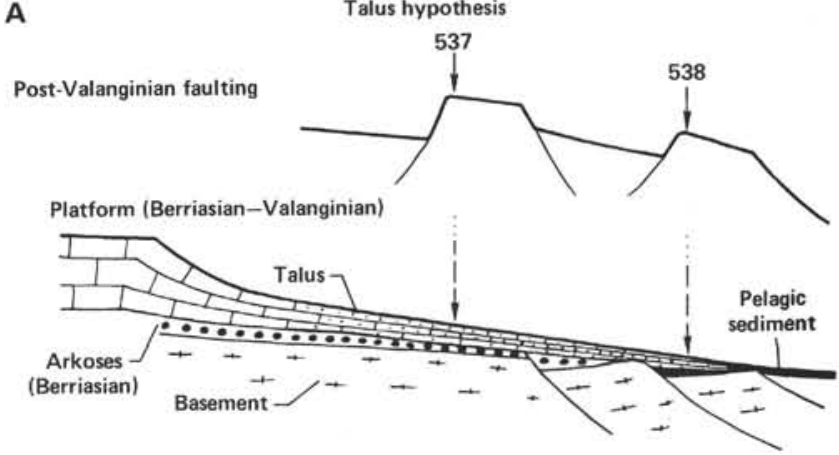

B Platform hypothesis

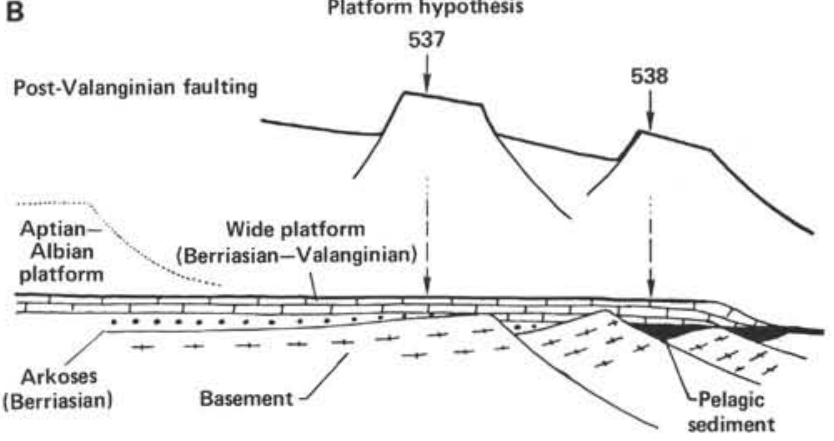

Figure 17. Two contrasting interpretations of Early Cretaceous limestones at Sites 537 and 538. A. Talus hypothesis assumes that limestones are talus originating at Campeche Bank and shed down a gently dipping seafloor. Talus apron would have to be $30 \mathrm{~km}$ wide. B. Platform hypothesis interprets limestones as part of extensive Jurassic-Early Cretaceous platform that was partly drowned and forced to "step back" in Valanginian time. High Aptian-Albian platform (present-day Campeche Bank, dotted line) grew on top of this Valanginian platform. Both models call for block faulting before and after deposition of the Berriasian-Valanginian limestone interval. 


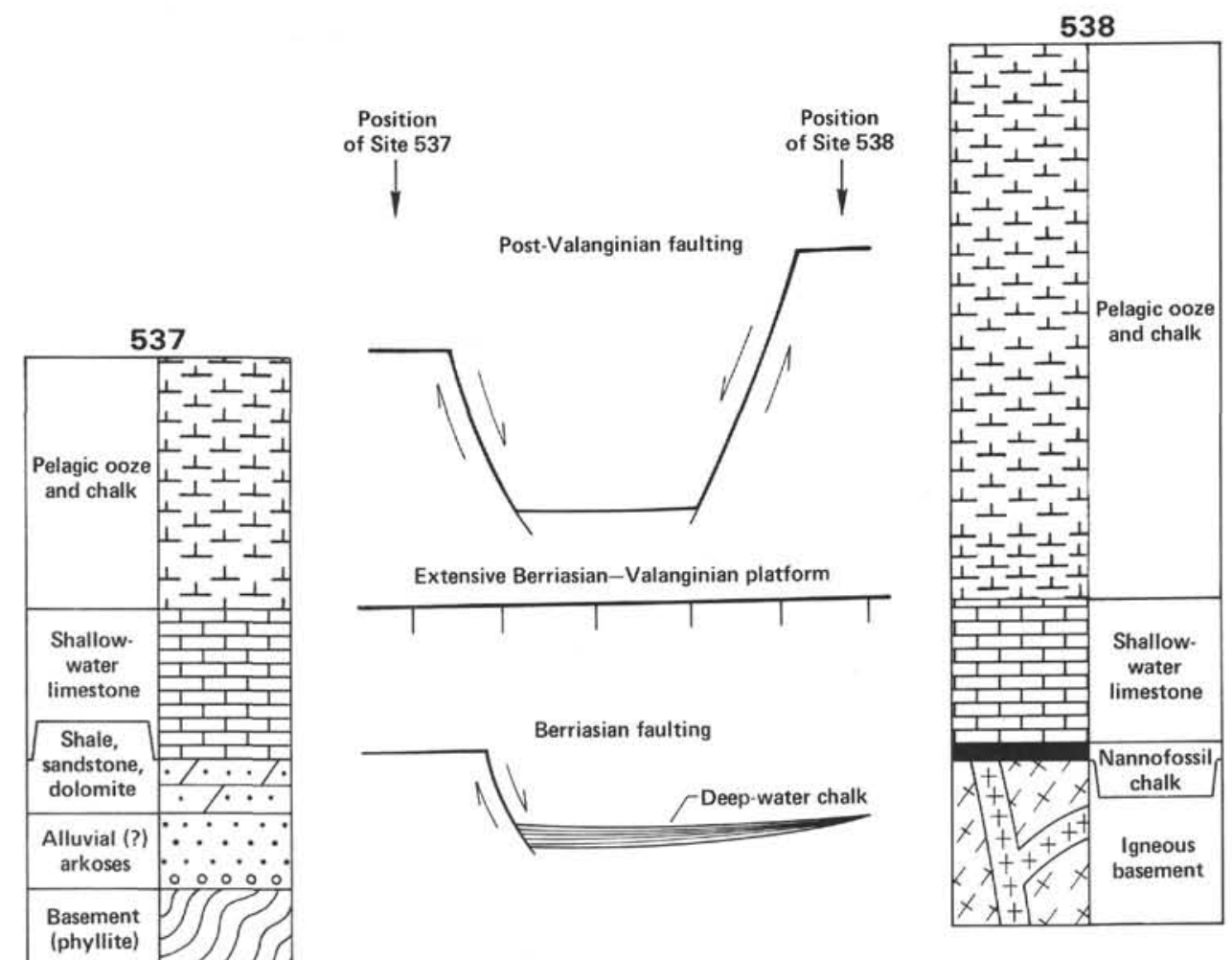

Figure 18. Stratigraphy of Sites 537 and 538, located on two separate fault blocks $27 \mathrm{~km}$ apart. Differences are explained by the interplay of tectonics and sedimentation, shown schematically in center of figure: faulting in Berriasian, followed by undisturbed growth of a carbonate platform (late Berriasian-Valanginian) and renewed faulting in post-Valanginian time.
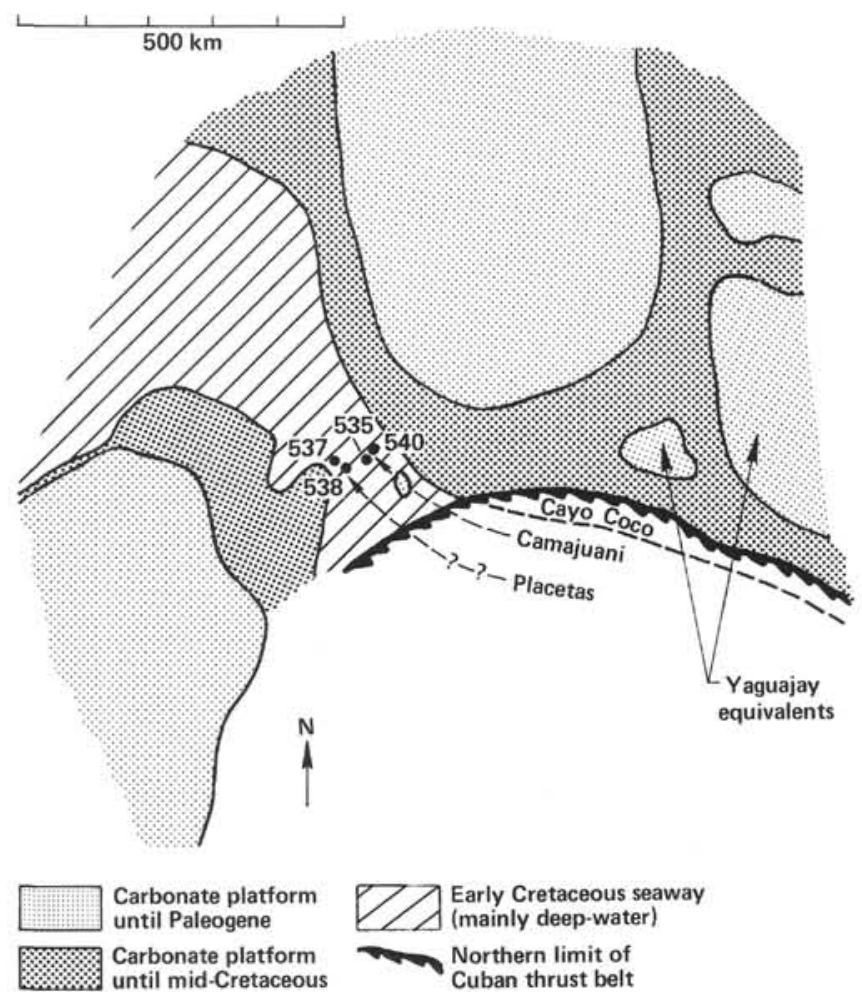

Figure 19. Cretaceous-Tertiary paleogeography of southeastern Gulf of Mexico and postulated relations to facies-structural zones of Cuba. Positions of zones in Cuban thrust belt are schematic and not to scale. 


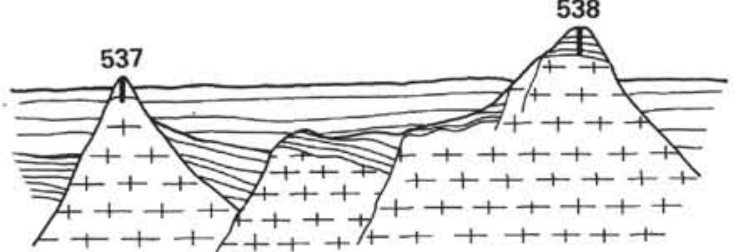

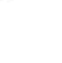
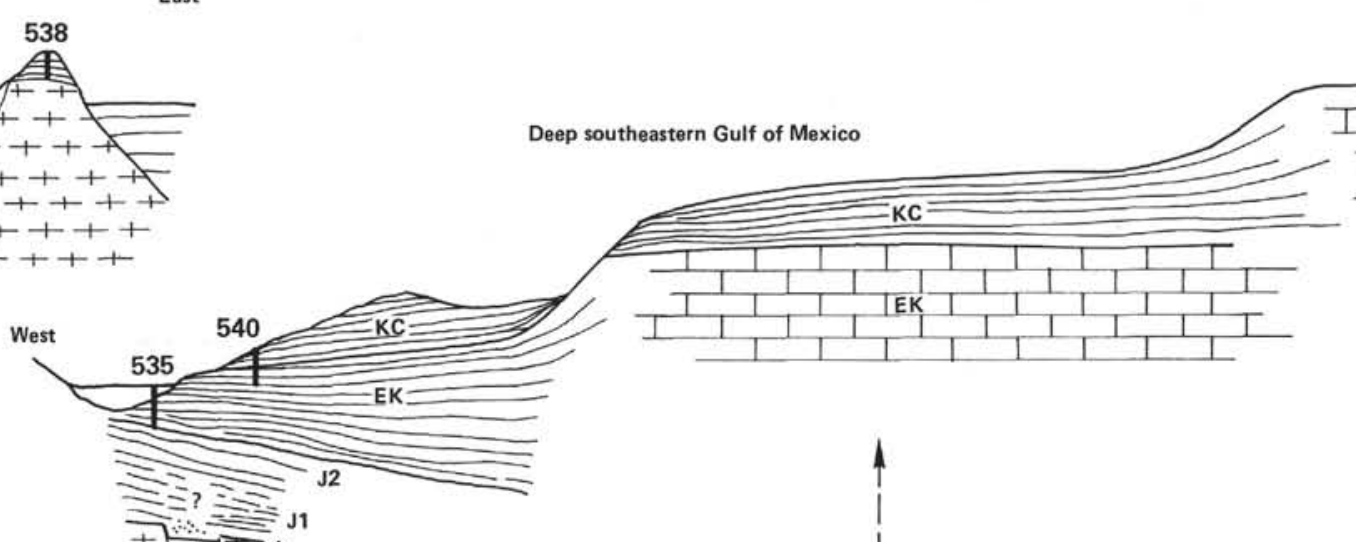

$+7+7$

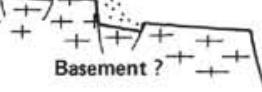

$\sqrt{12}$

$$
\text { 些 }
$$

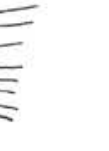

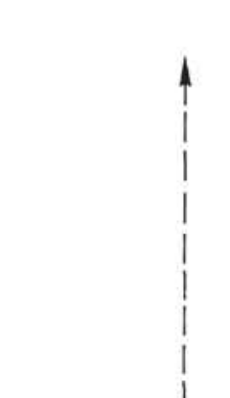

CAMAJUANI

CAYO COCO

\begin{tabular}{lll|}
\hline & 1 & \\
\hline & &
\end{tabular}

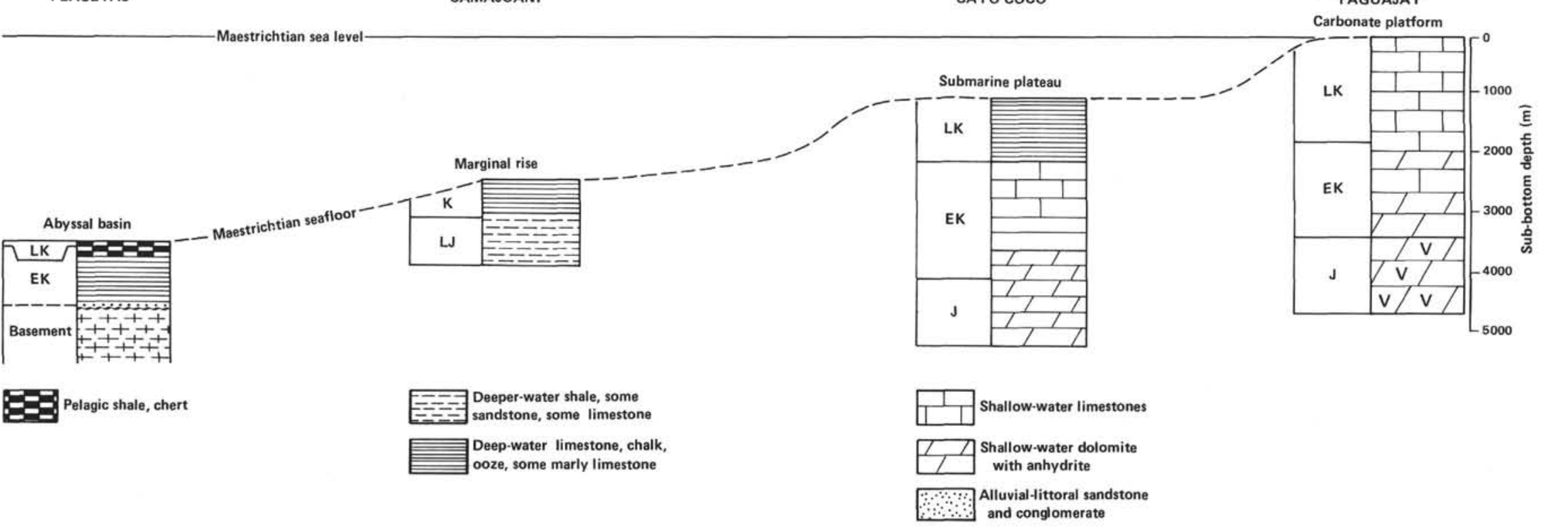

Figure 20. Correlation of structural-stratigraphic zones in southeastern Gulf of Mexico with facies-structural zones in central Cuba. Schematic cross-sections of Gulf of Mexico based on UTIG seismics and DSDP drilling; stratigraphy of zones in Cuba after Pardo (1975) and Pszczolkowski (1982). This comparison suggests that the eastern margin of the southeastern Gulf and its continuation now exposed on Cuba had very similar topography. Shale and chert in the Placetas Zone of Cuba represent the deepest part of the Cretaceous seaway; no equivalents were recovered in the Gulf. 